Review

\title{
Recent Advances in the Use of Sodium Borohydride as a Solid State Hydrogen Store
}

\section{Jianfeng Mao and Duncan H. Gregory*}

WestCHEM, School of Chemistry, University of Glasgow, Joseph Black Building, Glasgow G12 8QQ, UK; E-Mail: jfmao@umd.edu

* Author to whom correspondence should be addressed; E-Mail: duncan.gregory@glasgow.ac.uk; Tel.: +44-141-330-6438; Fax: +44-141-330-4888.

Academic Editor: Craig M. Jensen

Received: 22 October 2014 / Accepted: 15 December 2014 / Published: 13 January 2015

\begin{abstract}
The development of new practical hydrogen storage materials with high volumetric and gravimetric hydrogen densities is necessary to implement fuel cell technology for both mobile and stationary applications. $\mathrm{NaBH}_{4}$, owing to its low cost and high hydrogen density (10.6 wt\%), has received extensive attention as a promising hydrogen storage medium. However, its practical use is hampered by its high thermodynamic stability and slow hydrogen exchange kinetics. Recent developments have been made in promoting $\mathrm{H}_{2}$ release and tuning the thermodynamics of the thermal decomposition of solid $\mathrm{NaBH}_{4}$. These conceptual advances offer a positive outlook for using $\mathrm{NaBH}_{4}$-based materials as viable hydrogen storage carriers for mobile applications. This review summarizes contemporary progress in this field with a focus on the fundamental dehydrogenation and rehydrogenation pathways and properties and on material design strategies towards improved kinetics and thermodynamics such as catalytic doping, nano-engineering, additive destabilization and chemical modification.
\end{abstract}

Keywords: hydrogen; hydride; sodium borohydride; hydrogen storage

\section{Introduction}

With concerning current trends in environmental pollution and depletion of fossil energy resources, there is an imperative to seek renewable and clean energy sources that can support the continued 
sustainable development of human society. Hydrogen is regarded as one of the best alternative sustainable energy carriers because of its abundance, high energy density and lack of adverse environmental impact (for example, when oxidized as water). However, an important challenge for the use of hydrogen for mobile (e.g., automotive) and small scale energy generation is how to achieve safe, cheap, high density storage [1]. Essentially, hydrogen can be stored either in a physical form (as a gas or liquid) or in a chemical form (e.g., within metal hydrides or so-called chemical hydrides). Compressed gas and liquid hydrogen storage technologies represent the current state-of-the art, but more compact (gravimetrically and/or volumetrically efficient) means of storing hydrogen are needed for mobile applications on a practical level. In principle, solid state hydrogen storage in metal hydrides is considered a more effective and safer way to handle hydrogen than its storage as either a compressed gas or cryogenic liquid. The hydrides offer volumetric hydrogen densities substantially greater than that of compressed gas and comparable to or exceeding that of liquid hydrogen but without the requirement of very high pressure containment vessels or cryogenic tanks [2-4]. An ideal on-board hydrogen storage material will have a low molar weight, be inexpensive, have rapid kinetics for absorbing and desorbing $\mathrm{H}_{2}$ in the $25-120{ }^{\circ} \mathrm{C}$ temperature range, and store large quantities of hydrogen reversibly [5]. Recently, light metal borohydrides such as $\mathrm{NaBH}_{4}$ [6-8], $\mathrm{LiBH}_{4}$ [9-12], $\mathrm{Mg}\left(\mathrm{BH}_{4}\right)_{2}$ [13-15], and $\mathrm{Ca}\left(\mathrm{BH}_{4}\right)_{2}$ [16-18] have attracted much attention as potential hydrogen storage media primarily due to their high gravimetric capacities. The physical and chemical properties of these borohydrides are shown in Table 1 [19,20]. Perhaps compared to the borohydrides of lithium, magnesium and calcium there has been little focus on $\mathrm{NaBH}_{4}$ for hydrogen storage in the solid state due to its relatively much higher decomposition temperature. Given that the decomposition temperature of $\mathrm{NaBH}_{4}$ at 1 bar of $\mathrm{H}_{2}$ is in excess of $500{ }^{\circ} \mathrm{C}$, the required operating temperature for a store would considerably exceed that required for practical application in hydrogen fuel cell vehicles [7]. This fact alone explains why most previous research has been conducted on the hydrolysis of $\mathrm{NaBH}_{4}$ for hydrogen generation rather than its thermolysis as part of a solid state storage system [21]. However, the gravimetric hydrogen storage capacity of real hydrolysis-based storage systems will invariably be lower than the theoretical $10.6 \mathrm{wt} \%$ figure due to the excess water required to dissolve the $\mathrm{NaBH}_{4}$ and its by-product, $\mathrm{NaBO}_{2}$, as well as the added mass of the reaction and storage vessels. Hence, the U.S. Department of Energy (US DOE) issued a "No-Go" recommendation for the hydrolysis of $\mathrm{NaBH}_{4}$ in 2007, and since then the approach has no longer been seriously considered for automotive applications [22].

Table 1. Physical and chemical properties of borohydrides.

\begin{tabular}{|c|c|c|c|c|c|}
\hline Borohydride & Cost ${ }^{a} /($ USD/g) & $\begin{array}{l}\text { Hydrogen } \\
\text { density/wt\% }\end{array}$ & $T_{\mathrm{d}} \mathrm{b} /{ }^{\circ} \mathbf{C}$ & Reaction & References \\
\hline $\mathrm{NaBH}_{4}$ & 6.47 & 10.6 & 505 & $\mathrm{NaBH}_{4} \rightarrow \mathrm{Na}+\mathrm{B}+2 \mathrm{H}_{2}$ & {$[6-8]$} \\
\hline $\mathrm{LiBH}_{4}$ & 15.65 & 18.5 & 380 & $\mathrm{LiBH}_{4} \rightarrow \mathrm{Li}+\mathrm{B}+2 \mathrm{H}_{2}$ & [9-12] \\
\hline $\operatorname{Mg}\left(\mathrm{BH}_{4}\right)_{2}$ & 116.5 & 14.9 & 320 & $\mathrm{Mg}\left(\mathrm{BH}_{4}\right)_{2} \rightarrow \mathrm{MgB}_{2}+4 \mathrm{H}_{2}$ & {$[13-15]$} \\
\hline $\mathrm{Ca}\left(\mathrm{BH}_{4}\right)_{2}$ & 142 & 11.6 & 367 & $\begin{array}{c}\mathrm{Ca}\left(\mathrm{BH}_{4}\right)_{2} \rightarrow 2 / 3 \mathrm{CaH}_{2}+ \\
1 / 3 \mathrm{CaB}_{6}+10 / 3 \mathrm{H}_{2}\end{array}$ & [16-18] \\
\hline
\end{tabular}

${ }^{a}$ Prices from Sigma-Aldrich [23] for hydrogen storage grade materials; and ${ }^{\mathrm{b}}$ dehydrogenation temperature. 
However, use of solid $\mathrm{NaBH}_{4}$ for hydrogen storage has many advantages. Compared to other borohydrides, $\mathrm{NaBH}_{4}$ is cheaper and relatively stable in air [24]. For $\mathrm{NaBH}_{4}$ to be suitable for practical applications, the desorption temperature must be reduced and appreciable cyclability must be demonstrated. Over the last several years some novel strategies such as catalysis, nano-engineering, additive destabilization and chemical modification have been employed to address the thermodynamic and kinetic limitations of the thermal decomposition of $\mathrm{NaBH}_{4}$. While $\mathrm{NaBH}_{4}$ is not yet the solution to the problem of facile storage of hydrogen in the solid state, the progress of the various methodologies in improving both performance and understanding of this performance has been highly encouraging and hence we focus on these advances in this review. The primary purpose of this paper is to consider progress largely from 2009 onwards, comparing what is known regarding the decomposition behavior and mechanism of pristine $\mathrm{NaBH}_{4}$ with materials modified using the approaches listed above and the prospects of such systems for practical exploitation.

\section{Thermal Decomposition}

$\mathrm{NaBH}_{4}$ adopts a NaCl-type structure at ambient conditions in which four hydrogen atoms are covalently stabilized within the $\mathrm{BH}_{4}^{-}$anion, which in turn is bonded essentially ionically to the counter-cation $\mathrm{Na}^{+}$[24]. The complete hydrogen desorption reaction of $\mathrm{NaBH}_{4}$ can be expressed as follows:

$$
\mathrm{NaBH}_{4} \rightarrow \mathrm{Na}+\mathrm{B}+2 \mathrm{H}_{2} \quad 10.6 \mathrm{wt} \%
$$

However, like many other borohydrides, the real decomposition process of $\mathrm{NaBH}_{4}$ is likely to be more complex and involve intermediate phases such as $\mathrm{NaH}, \mathrm{Na}_{2} \mathrm{~B}_{12} \mathrm{H}_{12}$, or even release impurity gases such as $\mathrm{B}_{2} \mathrm{H}_{6}$ [6]. Recent theoretical and experimental studies have provided insight into its decomposition behavior as well as identifying the extent of the challenges ahead in developing $\mathrm{NaBH}_{4}$ as a viable hydrogen carrier.

First principles calculations suggest a scenario where $\mathrm{BH}_{4}{ }^{-}$ions decompose at the surface of $\mathrm{NaBH}_{4}$ into $\mathrm{H}^{-}$ions and $\mathrm{BH}_{3}$ molecules [25]. The $\mathrm{H}^{-}$ions remain in the lattice, locally converting $\mathrm{NaBH}_{4}$ into $\mathrm{NaH}$. The $\mathrm{BH}_{3}$ molecules originating from the decomposition can escape to the gas phase and form $\mathrm{B}_{2} \mathrm{H}_{6}$ (diborane) molecules, for instance. Alternatively, they may decompose immediately to form hydrogen and B. However, there is no direct evidence from mass spectrometry data of $\mathrm{B}_{2} \mathrm{H}_{6}$ release during the decomposition of $\mathrm{NaBH}_{4}$ [6]. Despite this lack of experimental evidence, it remains possible that $\mathrm{NaBH}_{4}$ decomposition may involve diborane emission, as is seen in the thermal decomposition of less stable borohydrides [20]. Due to the high temperature necessary for decomposition on the one hand and the low thermal stability of diborane on the other, most of the diborane decomposes into the elements. At the same time, some of the gaseous species may react with remaining $\mathrm{NaBH}_{4}$ to form $\mathrm{Na}_{2} \mathrm{~B}_{12} \mathrm{H}_{12}$.

Martelli et al. [7] investigated the stability and hydrogen desorption of $\mathrm{NaBH}_{4}$ via dynamic pressure, composition, and temperature (PCT) measurements under constant hydrogen flows. It was found that only one plateau is visible in the isotherms, indicating that the decomposition occurs in one step (Figure 1). From the van't Hoff equation, the enthalpy and entropy of reaction are $-108 \pm 3 \mathrm{~kJ}^{\mathrm{mol}} \mathrm{m}^{-1}$ of $\mathrm{H}_{2}$ and $133 \pm 3 \mathrm{~J} \cdot \mathrm{K}^{-1} \cdot \mathrm{mol}^{-1}$ of $\mathrm{H}_{2}$ respectively. This corresponds to a decomposition temperature, 
$T_{\mathrm{d}}=534 \pm 10{ }^{\circ} \mathrm{C}$ at 1 bar of $\mathrm{H}_{2}$. The high stability of $\mathrm{NaBH}_{4}$ leads to a dehydrogenation temperature that is above the decomposition temperature of $\mathrm{NaH}$ [26].

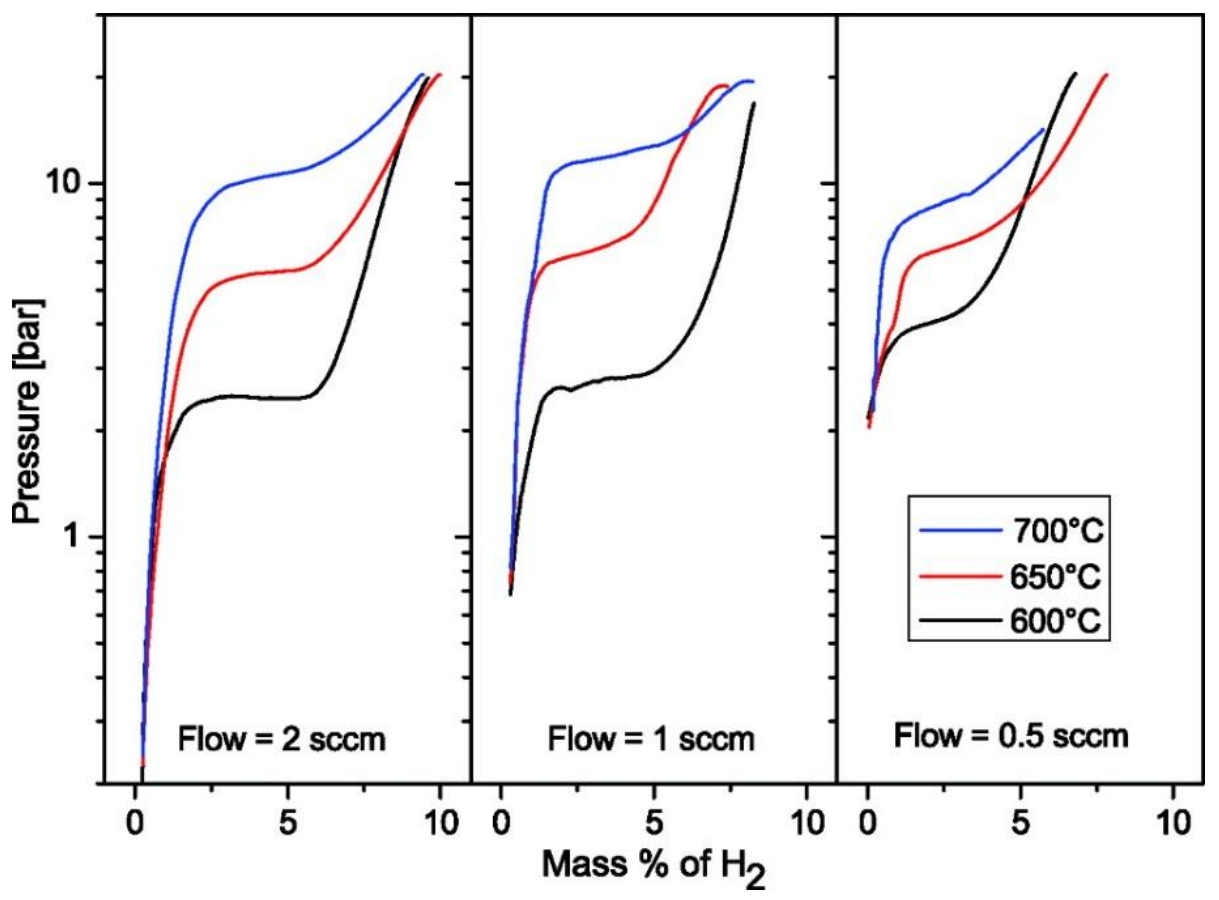

Figure 1. Pressure, composition, and temperature (PCT) isotherms measured on $\mathrm{NaBH}_{4}$ at a constant hydrogen flow of 2, 1, and $0.5 \mathrm{~cm}^{3}$ (STP) $\min ^{-1}$ [7]. Reprinted with permission from [7], copyright 2010 The American Chemical Society.

Therefore, $\mathrm{NaH}$ is thermodynamically unstable under the decomposition conditions of $\mathrm{NaBH}_{4}$ and will decompose into the corresponding elements without changing the observed equilibrium pressure. This rationalises the experimental analysis that $\mathrm{Na}$ is contained in the residue (as either $\mathrm{Na}$ or $\mathrm{NaH}$ ). A second phase in the product was identified as either elemental boron or a boron-rich phase [7]. The Na:NaH ratio in the residue is determined by the reaction kinetics involved. The presence of traces of $\mathrm{NaH}$ in the product shows that $\mathrm{NaBH}_{4}$ decays at least partially via $\mathrm{NaH}$, which confirms the theoretical prediction [25].

Recently, the boron-containing intermediate phase $\mathrm{Na}_{2} \mathrm{~B}_{12} \mathrm{H}_{12}$ was found experimentally during the decomposition of $\mathrm{NaBH}_{4}$ (and its composites). For example, Mao et al. [27] confirmed the formation of $\mathrm{Na}_{2} \mathrm{~B}_{12} \mathrm{H}_{12}$ by Fourier transform infrared spectroscopy (FTIR) in the decomposition of $\mathrm{TiF}_{3}$-doped $\mathrm{NaBH}_{4}$ or $\mathrm{CaH}_{2}-6 \mathrm{NaBH}_{4}$ and $\mathrm{Ca}\left(\mathrm{BH}_{4}\right)_{2}-4 \mathrm{NaBH}_{4}$ composites. In contrast, Garroni et al. [28] detected amorphous $\mathrm{Na}_{2} \mathrm{~B}_{12} \mathrm{H}_{12}$ by nuclear magnetic resonance (NMR) in partially dehydrogenated $2 \mathrm{NaBH}_{4}-\mathrm{MgH}_{2}$ and in the final products of the decomposition reaction. More recently, Ngene et al. [29] detected $\mathrm{Na}_{2} \mathrm{~B}_{12} \mathrm{H}_{12}$ with ${ }^{11} \mathrm{~B}$ solid state $\mathrm{NMR}$ after the dehydrogenation of a nanoconfined $\mathrm{NaBH}_{4} /$ porous carbon material. The formation mechanism of $\mathrm{Na}_{2} \mathrm{~B}_{12} \mathrm{H}_{12}$ is not yet clear; the borohydride may originate from the reaction of boranes with unreacted $\mathrm{NaBH}_{4}$, which was proposed by the first principles calculations [25]. In fact, a similar decomposition route was proposed for $\mathrm{LiBH}_{4}$, where Friedrichs et al. [30] suggested that the formation of $\mathrm{Li}_{2} \mathrm{~B}_{12} \mathrm{H}_{12}$ arises from the reaction of the borane evolving from $\mathrm{LiBH}_{4}$ with the remaining starting material. First principles calculations suggest that $\mathrm{Na}_{2} \mathrm{~B}_{12} \mathrm{H}_{12}$ has significant ionic character and is relatively stable and if it was formed during the thermal 
decomposition of $\mathrm{NaBH}_{4}$, thermodynamically one would not expect its existence to be fleeting [31]. Moreover, because of its anticipated low reactivity with hydrogen, when formed it might be expected to represent a limiting step in the reverse reaction to the fully hydrogenated $\mathrm{NaBH}_{4}$. In this regard, further research is required to evaluate the effects of the formation of $\mathrm{Na}_{2} \mathrm{~B}_{12} \mathrm{H}_{12}$ on both the $\mathrm{NaBH}_{4}$ dehydrogenation and its subsequent re-hydrogenation.

\section{Strategies for Promoting $\mathrm{H}_{2}$ Release from Solid-State Thermolysis of $\mathrm{NaBH}_{4}$}

From the point where $\mathrm{NaBH}_{4}$ hydrolysis was no longer considered for automotive applications by the US DOE, solid-state thermolysis has become the only realistic option for the practical use of the borohydride in hydrogen storage applications. Before this can happen, however, the kinetic and thermodynamic limitations associated with the (de)hydrogenation of $\mathrm{NaBH}_{4}$ must be removed. To this end, several strategies have recently been developed and proven effective in improving the thermally activated $\mathrm{H}_{2}$ release from $\mathrm{NaBH}_{4}$ and these are considered below.

\subsection{Catalytic Doping}

Catalysts play an important role in the hydrogen sorption processes in hydrides, since they improve the hydrogen uptake and release kinetics by reducing the activation barrier for diffusion and facilitating hydrogen dissociation. Therefore, it is of particular interest to use catalysts to promote hydrogen exchange reactions in $\mathrm{NaBH}_{4}$ under moderate temperature and pressure conditions.

Mao et al. [32] investigated the effects of Ti-based additives, including $\mathrm{Ti}, \mathrm{TiH}_{2}$, and $\mathrm{TiF}_{3}$, on the dehydrogenation of $\mathrm{NaBH}_{4}$. It was revealed that all of the titanium-based additives were effective in improving the hydrogen desorption and absorption reactions of $\mathrm{NaBH}_{4}$ and among them $\mathrm{TiF}_{3}$ possessed the highest catalytic activity (Figure 2). Powder X-ray diffraction (PXD) and X-ray photoelectron spectroscopy (XPS) revealed that the dehydrogenation of $\mathrm{TiF}_{3}$-doped $\mathrm{NaBH}_{4}$ can be regarded as a two-step process: (i) the thermodynamically-favorable reaction between borohydride and fluoride at $c a .300{ }^{\circ} \mathrm{C}\left(3 \mathrm{NaBH}_{4}+\mathrm{TiF}_{3} \rightarrow 3 \mathrm{NaF}+\mathrm{TiB}_{2}+\mathrm{B}+6 \mathrm{H}_{2}\right)$; and (ii) the dehydrogenation of the remaining $\mathrm{NaBH}_{4}$, catalysed by the $\mathrm{NaF}$ and $\mathrm{TiB}_{2}$ formed in situ in step (i). The $\mathrm{TiF}_{3}$-doped sample demonstrates good reversibility with $\mathrm{ca} .4 \mathrm{wt} \%$ hydrogen absorbed below $500{ }^{\circ} \mathrm{C}$ at $5.5 \mathrm{MPa}$.

$\mathrm{Ni}$-containing additives including $\mathrm{Ni}(20 \mathrm{~nm}), \mathrm{Ni} 3 \mathrm{~B}, \mathrm{NiCl}_{2}, \mathrm{NiF}_{2}$, and $\mathrm{Ni}(65 \mathrm{wt} \%)$ supported on $\mathrm{Si} / \mathrm{Al}_{2} \mathrm{O}_{3}$ reduce the dehydrogenation temperature of $\mathrm{NaBH}_{4}$ by at least $60{ }^{\circ} \mathrm{C}$ (e.g., $65 \mathrm{wt} \% \mathrm{Ni}$ on $\mathrm{Si} / \mathrm{Al}_{2} \mathrm{O}_{3}$ ) [33]. PXD analysis has indicated that $\mathrm{Ni}$ reacts with $\mathrm{B}$ evolved during the thermal decomposition of $\mathrm{NaBH}_{4}$ to form $\mathrm{Ni}_{x} \mathrm{~B}_{y}$ species including $\mathrm{Ni}_{3} \mathrm{~B}, \mathrm{Ni}_{2} \mathrm{~B}$, and $\mathrm{Ni}_{3} \mathrm{~B}_{4}$. The thermodynamically favorable formation of these species is likely one reason why the dehydrogenation temperature is reduced. The reversibility is poor however and re-hydrogenation forms $\mathrm{NaH}$ with a maximum hydrogen uptake of $c a .2 \mathrm{wt} \%$ and no activity to hydrogenation from the additives evident. The authors also conducted a catalyst screening study of $\mathrm{NaBH}_{4}$ with a variety of metal nanoparticles, chlorides, borides, and mesoporous materials. The most effective catalysis was performed by Pd nanoparticles inducing a desorption temperature of $420{ }^{\circ} \mathrm{C}$; a decrease of at least $85{ }^{\circ} \mathrm{C}$ compared to pristine $\mathrm{NaBH}_{4}$. By analogy to the nickel additives above, the reduction in dehydrogenation temperature is probably enabled by the formation of $\mathrm{Pd}_{x} \mathrm{~B}_{y}$ intermediate phases. The reversibility of hydrogen uptake and release in the system incorporating $\mathrm{Pd}\left(\mathrm{Pd}_{x} \mathrm{~B}_{y}\right)$ has yet to be reported. 


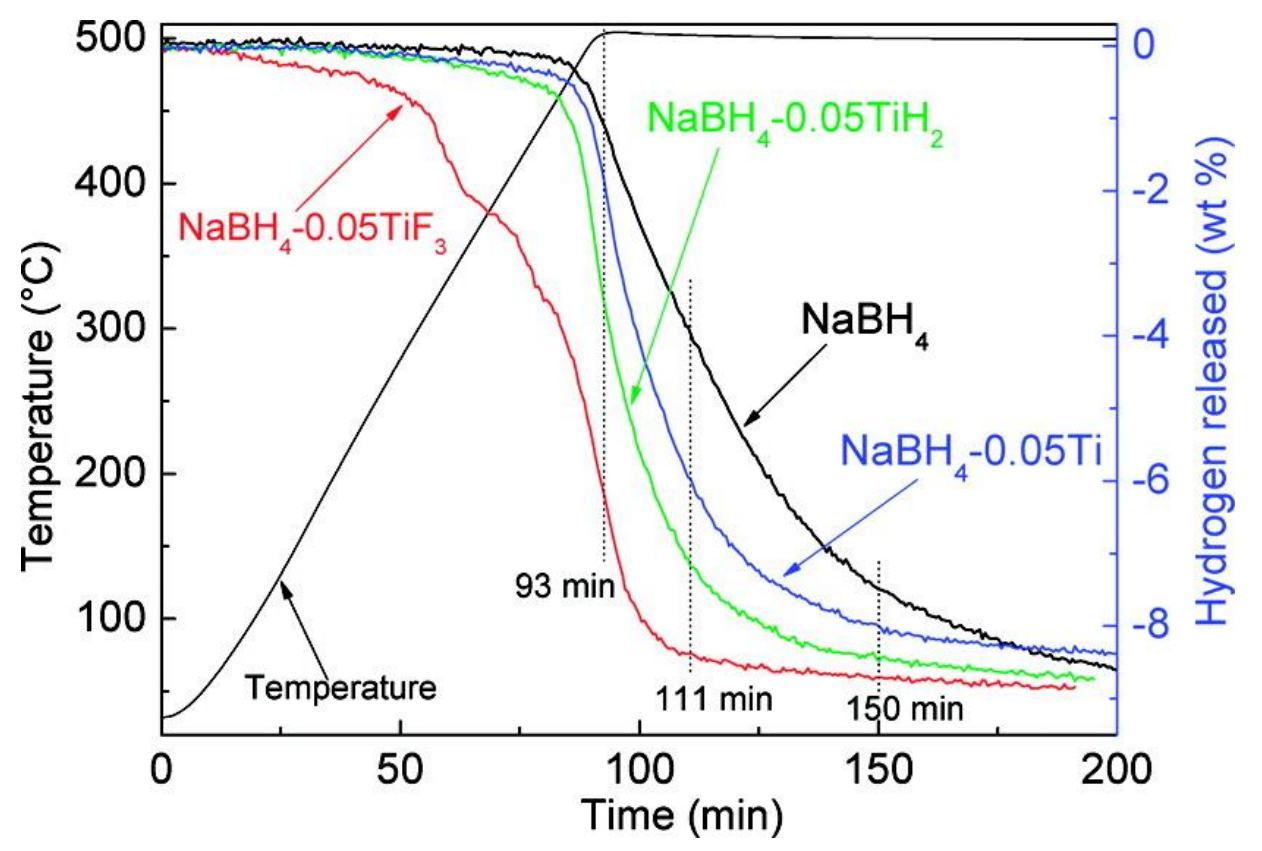

Figure 2. Temperature-programmed desorption (TPD) profiles of $\mathrm{NaBH}_{4}$ with and without different titanium catalysts. The heating rate was $5{ }^{\circ} \mathrm{C} \cdot \min ^{-1}[32]$. Reprinted with permission from [32], copyright 2012 The American Chemical Society.

\subsection{Nano-Engineering}

It is well-documented that the physical and chemical properties of nanoparticles can be very different from those of the corresponding bulk materials [34]. Reducing the particle size of the metal hydride to the nanometer range can result in enhanced kinetics and in some cases, modified thermodynamics.

Metal hydride nanoparticles or nanocomposites are usually prepared by high-energy ball milling. However, the lower range of particle sizes obtained from milling is typically limited to hundreds of nanometers and the particle size distribution is usually non-uniform. For $\mathrm{NaBH}_{4}$, Varin and Chiu [35] studied the variation of the cubic lattice parameter and crystallite (grain) size with milling times of up to $200 \mathrm{~h}$. It was found that the lattice parameter of the compound varies only modestly during prolonged milling (maximum $\sim 0.15 \%$ after $50 \mathrm{~h}$ ) and the average crystallite (grain) size remains of the order of a few tens of nanometers. Therefore, it seems that ball milling even under these relatively extreme conditions is rather limited in its ability to nanostructure $\mathrm{NaBH}_{4}$.

One sophisticated approach towards achieving genuinely nanoscale dimensions in the borohydride is to infiltrate the material into a mesoporous host matrix. Such approaches could improve the hydrogen uptake kinetics (and in some cases the thermodynamics) of hydrides significantly. Ampoumogli et al. [36] recently synthesized nanocomposites of $\mathrm{NaBH}_{4} / \mathrm{CMK}-3$ (an ordered mesoporous carbon) via the impregnation of the porous carbon with $\mathrm{NaBH}_{4}$ dissolved in liquid ammonia and showed that the nanocomposite releases hydrogen at lower temperatures than bulk $\mathrm{NaBH}_{4}$. Mass spectra however, showed that the released gases contained ammonia, which could either originate from solvent that is incorporated into the pores of the carbon or form a sodium borohydride ammine complex formed during the impregnation process. In contrast, by nano-confining $\mathrm{NaBH}_{4}$ in a highly-ordered Si-based mesoporous scaffold (SBA-15) and its carbon (CMK-3) replica, respectively, through ammonia-free wet chemical impregnation, it was possible to avoid the formation of 
unwanted by-products [37]. Temperature-programmed desorption (TPD) highlighted a notable reduction in dehydrogenation temperature compared to bulk $\mathrm{NaBH}_{4}$, but the details of the desorption pathway, associated structural evolution and reversibility in this system are not yet clear and require further study. Recently, Ngene et al. [29] synthesized $\mathrm{NaBH}_{4} / \mathrm{C}$ nanocomposites in which the pores of the matrix were of $2-3 \mathrm{~nm}$ in diameter. The materials were prepared using pore volume impregnation either with an aqueous $\mathrm{NaBH}_{4}$ solution (denoted SI) or via melt infiltration (MI). It was found that each method results in a lower dehydrogenation temperature compared to pristine $\mathrm{NaBH}_{4}$ [29]. The onset of hydrogen release can be reduced from $470{ }^{\circ} \mathrm{C}$ for the bulk borohydride to less than $250{ }^{\circ} \mathrm{C}$ for the nanocomposites (Figure 3). In these cases the dehydrogenated nanocomposites could be partially re-hydrogenated with the absorption of about $43 \%$ of the initial hydrogen capacity under $60 \mathrm{bar}_{2}$ at $325{ }^{\circ} \mathrm{C}$. The loss of capacity in this system was directly connected to partial loss of $\mathrm{Na}$ during dehydrogenation and this loss could be ameliorated (to retention of $98 \%$ of initial capacity) by adding further $\mathrm{Na}$ to the nanocomposites.

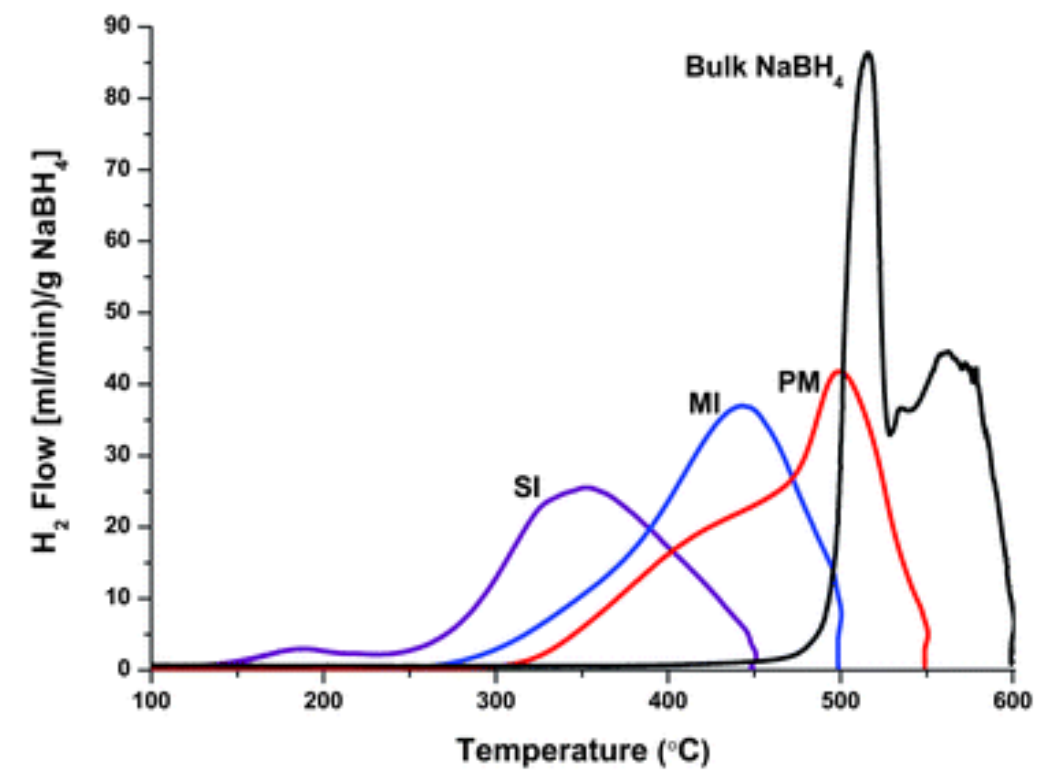

Figure 3. TPD experiments $\left(5^{\circ} \mathrm{C} \cdot \mathrm{min}^{-1}\right.$ under Ar) showing hydrogen release from bulk $\mathrm{NaBH}_{4}$ (black); a physical mixture of $25 \mathrm{wt} \% \mathrm{NaBH}_{4}$ and porous carbon (PM; red); solution impregnated $25 \mathrm{wt} \% \mathrm{NaBH}_{4} / \mathrm{C}$ nanocomposites (SI; purple) and melt infiltration (MI; blue) $25 \mathrm{wt} \% \mathrm{NaBH}_{4} / \mathrm{C}$ nanocomposites [29]. Reproduced from [29] with permission of The Royal Society of Chemistry.

Nano-confinement in porous matrices has become a well-traveled bridge connecting bulk and nanoscale hydrogen storage materials. In addition to the unique structures and size-specific chemistry of nanomaterials, the methodology is also expected to introduce a large number of defects. Moreover, the interactions between the $\mathrm{M}-\mathrm{H}$ bond and the internal surface of the nanopores may also contribute a catalytic effect to the desorption process. All these effects would promote dehydrogenation at lower temperatures. However, the weight penalty of the supporting substrates (hosts) will always reduce the gravimetric hydrogen storage capacity of the system.

In an alternative approach, Christian and Aguey-Zinsou [38,39] synthesized $\mathrm{NaBH}_{4}$ nanoparticles ( $<30 \mathrm{~nm}$ in diameter) by using an anti-solvent precipitation method. The procedure resulted in a decrease of the borohydride melting point and an initial release of hydrogen at $400{ }^{\circ} \mathrm{C} ; \mathrm{ca} .100{ }^{\circ} \mathrm{C}$ 
lower than the bulk material. Encapsulation of these nanoparticles upon reaction with nickel chloride yielded core-shell nanostructures, $\mathrm{NaBH}_{4} @ \mathrm{Ni}$. This core-shell material begins to release hydrogen at $50{ }^{\circ} \mathrm{C}$ with significant desorption from $350{ }^{\circ} \mathrm{C}$. Even more remarkably, the core-shell configuration engenders full reversibility to $\mathrm{NaBH}_{4}$ with hydrogen desorption/absorption occurring under $4 \mathrm{MPa}$ at $350{ }^{\circ} \mathrm{C}$ (Figure 4). A consistent reversible hydrogen capacity of $5 \mathrm{wt} \%$ was achieved for $\mathrm{NaBH}_{4} @ \mathrm{Ni}$, in which $80 \%$ of the hydrogen could be desorbed or absorbed in <60 min and full capacity could be achieved within $5 \mathrm{~h}$. Although these conditions are still far from the ideal requirements for practical applications, this work suggests that the hydrogen storage performance of $\mathrm{NaBH}_{4}$ can be altered dramatically by the integration of nano-engineering and catalysis concepts.

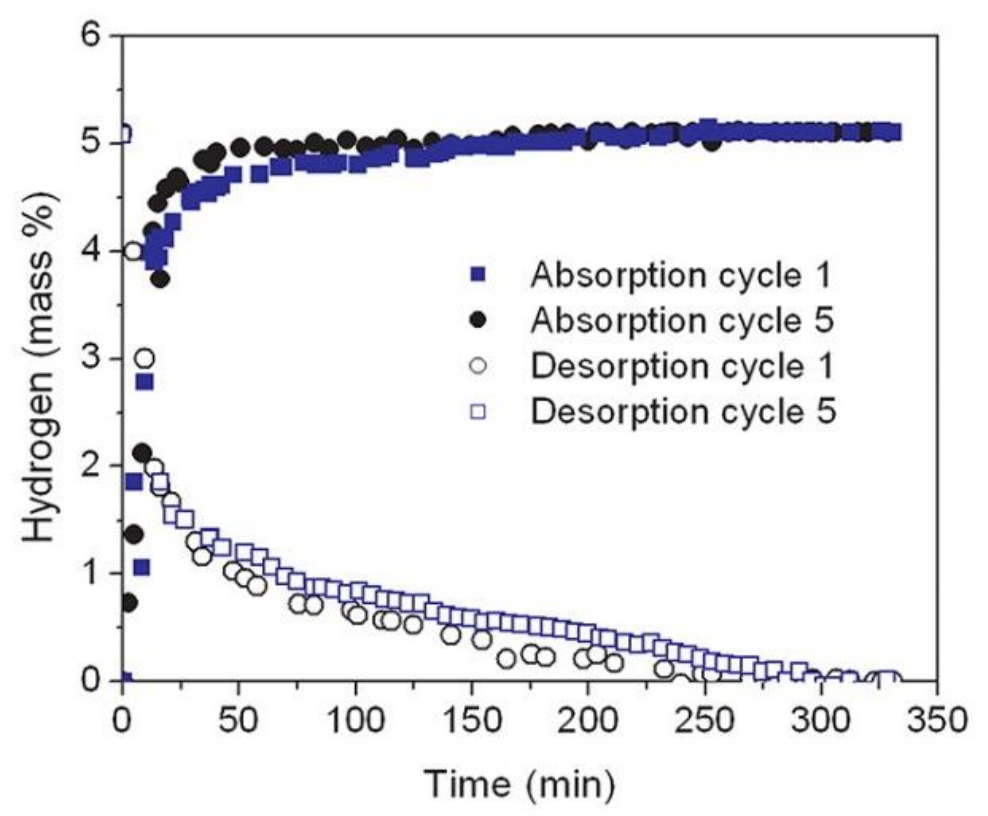

Figure 4. Kinetics of hydrogen desorption at $0.01 \mathrm{MPa}$ and absorption under $4 \mathrm{MPa}$ hydrogen pressure at $350{ }^{\circ} \mathrm{C}$ for $\mathrm{NaBH}_{4} @ \mathrm{Ni}$ [38]. Reprinted with permission from [38], copyright 2012 The American Chemical Society.

\subsection{Destabilization Using Reactive Additives}

Another possible way to lower the decomposition temperature of $\mathrm{NaBH}_{4}$ and further tune its thermodynamic and kinetic characteristics is by the use of certain select additives. As opposed to the use of catalysts, the additive employed in these cases not only promotes the kinetics, but also tunes the thermodynamics through changing the reaction pathway. For example, the dehydrogenation thermodynamics and kinetics of $\mathrm{NaBH}_{4}$ could be significantly improved by combining with fluorographite (FGi) according to the following reaction [40]:

$$
x \mathrm{NaBH}_{4}+4 \mathrm{CF}_{x} \rightarrow x \mathrm{NaBF}_{4}+4 \mathrm{C}+2 x \mathrm{H}_{2}(x=0.8-1)
$$

The dehydrogenation onset temperature of ball-milled $55 \mathrm{NaBH}_{4}-45 \mathrm{FGi}$ composites can be decreased to $125{ }^{\circ} \mathrm{C}$ and approximately $4.8 \mathrm{wt} \%$ hydrogen can be released at $130{ }^{\circ} \mathrm{C}$ over a period of several seconds. Such additives are usually mixed with the hydrides by high-energy milling. Several additives such as hydrides and fluorides, have been found to destabilize $\mathrm{NaBH}_{4}$ effectively and make the dehydrogenation or even hydrogenation possible at rather moderate pressures and temperatures. 


\subsubsection{Hydride Destabilization}

An important potential advantage in using hydrides as a destabilizing additive over others, is that in addition to the tuning of the thermodynamics and kinetics of (de)hydrogenation, it is possible to maintain a high gravimetric capacity. For example, $\mathrm{MgH}_{2}$ has been used successfully to modify the (de)hydrogenation thermodynamics relative to $\mathrm{NaBH}_{4}$ by forming the compound $\mathrm{MgB}_{2}$ upon dehydrogenation $[41,42]$. The main dehydrogenation reaction can either proceed to formation of $\mathrm{NaH}$ or sodium depending on the conditions:

$$
\begin{array}{ll}
2 \mathrm{NaBH}_{4}+\mathrm{MgH}_{2} \rightarrow 2 \mathrm{NaH}+\mathrm{MgB}_{2}+4 \mathrm{H}_{2} & 7.8 \mathrm{wt} \% \\
2 \mathrm{NaBH}_{4}+\mathrm{MgH}_{2} \rightarrow 2 \mathrm{Na}+\mathrm{MgB}_{2}+5 \mathrm{H}_{2} & 9.8 \mathrm{wt} \%
\end{array}
$$

This concept is called destabilization in a "reactive hydride composite (RHC)" in which two or more hydrides are combined in appropriate ratios to lower the dehydrogenation enthalpy of the system through forming a new hydrogen-free, thermodynamically stable compound as a by-product. Hence the desorption temperature is reduced and the reversibility of the system is improved [43].

By employing this strategy, the dehydrogenation of $\mathrm{NaBH}_{4}$ can be facilitated by combining the borohydride with other metal hydrides such as $\mathrm{LiAlH}_{4}, \mathrm{Ca}\left(\mathrm{BH}_{4}\right)_{2}$ and $\mathrm{CaH}_{2}$ so as to form $\mathrm{LiAl}, \mathrm{AlB}_{2}$ and $\mathrm{CaB}_{6}$ respectively upon dehydrogenation [27,44]:

$$
\begin{array}{rr}
2 \mathrm{NaBH}_{4}+2 \mathrm{LiAlH}_{4} \rightarrow 2 \mathrm{Na}+\mathrm{AlB}_{2}+\mathrm{LiAl}+8 \mathrm{H}_{2} & 10.6 \mathrm{wt} \% \\
4 \mathrm{NaBH}_{4}+\mathrm{Ca}\left(\mathrm{BH}_{4}\right)_{2} \rightarrow 4 \mathrm{Na}+\mathrm{CaB}_{6}+12 \mathrm{H}_{2} & 10.9 \mathrm{wt} \% \\
6 \mathrm{NaBH}_{4}+\mathrm{CaH}_{2} \rightarrow 6 \mathrm{Na}+\mathrm{CaB}_{6}+13 \mathrm{H}_{2} & 9.7 \mathrm{wt} \%
\end{array}
$$

Similarly, addition of $\mathrm{Mg}_{2} \mathrm{NiH}_{4}$ to $\mathrm{NaBH}_{4}$ leads to formation of the stable ternary boride phase $\mathrm{MgNi}_{2.5} \mathrm{~B}_{2}$ and lowers the enthalpy of hydrogen desorption for $\mathrm{NaBH}_{4}$ from $110 \mathrm{~kJ} \cdot \mathrm{mol}^{-1} \mathrm{H}_{2}$ to $76 \pm 5 \mathrm{~kJ} \cdot \mathrm{mol}^{-1} \mathrm{H}_{2}$, according to the following reaction [45]:

$$
4 \mathrm{NaBH}_{4}+5 \mathrm{Mg}_{2} \mathrm{NiH}_{4} \rightarrow 4 \mathrm{NaH}+2 \mathrm{MgNi}_{2.5} \mathrm{~B}_{2}+8 \mathrm{Mg}+16 \mathrm{H}_{2} \quad 4.5 \mathrm{wt} \%
$$

As a consequence of this addition, the onset temperature of hydrogen desorption decreases from ca. $500{ }^{\circ} \mathrm{C}$ for $\mathrm{NaBH}_{4}$ to $360{ }^{\circ} \mathrm{C}$ for the $\mathrm{NaBH}_{4} / \mathrm{Mg}_{2} \mathrm{NiH}_{4}$ composite mixture. When $\mathrm{Mg}_{2} \mathrm{FeH}_{6}$ is added to $\mathrm{NaBH}_{4}$ the dehydrogenation can become quite complex [46]. A single dehydriding step is observed for $x \mathrm{NaBH}_{4}+(1-x) \mathrm{Mg}_{2} \mathrm{FeH}_{6}$ when $x=0.1$ and 0.125 , but a multi-step process occurs when $x>0.25$. Despite the different dehydriding process, PXD measurements maintain that $\mathrm{NaH}$ and $\mathrm{MgB}_{2}$ are the dehydrogenation products over the entire composition range. The results also indicate that the dehydriding temperature of $\mathrm{NaBH}_{4}$ is reduced by at least $150{ }^{\circ} \mathrm{C}$ when combined with $\mathrm{Mg}_{2} \mathrm{FeH}_{6}$.

As a model borohydride-hydride system, the $\mathrm{NaBH}_{4}-\mathrm{MgH}_{2}$ combination has been investigated extensively. For $2 \mathrm{NaBH}_{4}+\mathrm{MgH}_{2}$, the dehydrogenation temperature is reduced by $c a .40{ }^{\circ} \mathrm{C}$ compared to pure $\mathrm{NaBH}_{4}$ [41]. The desorption was originally proposed to follow a two-step process:

$$
\begin{aligned}
2 \mathrm{NaBH}_{4}+\mathrm{MgH}_{2} & \rightarrow 2 \mathrm{NaBH}_{4}+\mathrm{Mg}+\mathrm{H}_{2} \\
& \rightarrow 2 \mathrm{NaH}+\mathrm{MgB}_{2}+4 \mathrm{H}_{2}
\end{aligned}
$$

The dehydriding mechanism of the $2 \mathrm{NaBH}_{4}+\mathrm{MgH}_{2}$ system was subsequently suggested to proceed in three steps under 1 bar of inert gas, by: (i) the dehydrogenation of $\mathrm{MgH}_{2}$; (ii) the "disproportion" 
of $\mathrm{NaBH}_{4}$; and (iii) the reaction of an intermediate borohydride compound, such as $\mathrm{Na}_{2} \mathrm{~B}_{12} \mathrm{H}_{12}$, with free $\mathrm{Mg}$ to give $\mathrm{MgB}_{2}, \mathrm{NaH}$ and hydrogen [42,47]:

$$
\begin{aligned}
2 \mathrm{NaBH}_{4}+\mathrm{MgH}_{2} & \rightarrow \mathrm{Mg}+\mathrm{H}_{2}+2 \mathrm{NaBH}_{4} \\
& \rightarrow 1 / 6 \mathrm{Na}_{2} \mathrm{~B}_{12} \mathrm{H}_{12}+5 / 3 \mathrm{NaH}+\mathrm{Mg}+19 / 6 \mathrm{H}_{2} \\
& \rightarrow 2 \mathrm{NaH}+\mathrm{MgB}_{2}+4 \mathrm{H}_{2}
\end{aligned}
$$

However, no direct observation of $\mathrm{Na}_{2} \mathrm{~B}_{12} \mathrm{H}_{12}$ was made. When the reaction is performed under static vacuum, however, the dehydrogenation of $2 \mathrm{NaBH}_{4}-\mathrm{MgH}_{2}$ appears to follow an alternative pathway (Figure 5) [48]:

$$
\begin{aligned}
2 \mathrm{NaBH}_{4}+\mathrm{MgH}_{2} & \rightarrow 2 \mathrm{NaBH}_{4}+1 / 2 \mathrm{MgH}_{2}+1 / 2 \mathrm{Mg}+1 / 2 \mathrm{H}_{2} \\
& \rightarrow 3 / 2 \mathrm{NaBH}_{4}+1 / 4 \mathrm{MgB}_{2}+1 / 2 \mathrm{NaH}+3 / 4 \mathrm{Mg}+7 / 4 \mathrm{H}_{2} \\
& \rightarrow 2 \mathrm{Na}+\mathrm{B}+1 / 2 \mathrm{Mg}+1 / 2 \mathrm{MgB}_{2}+5 \mathrm{H}_{2}
\end{aligned}
$$

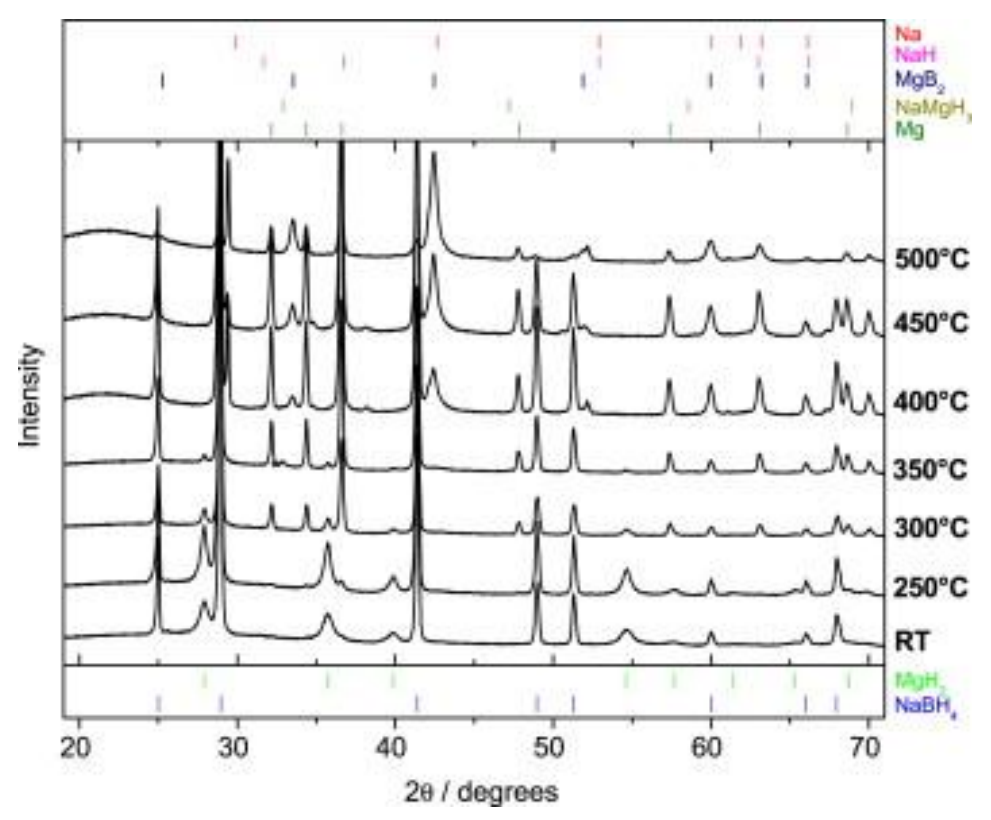

Figure 5. Powder X-ray diffraction (PXD) patterns of $2 \mathrm{NaBH}_{4}-\mathrm{MgH}_{2}$ with increasing temperature [48]. Reprinted from [48] with permission from the International Association of Hydrogen Energy.

The presence of the $\mathrm{B}_{12} \mathrm{H}_{12}{ }^{2-}$ anion was confirmed experimentally by solid state NMR. Amorphous $\mathrm{Na}_{2} \mathrm{~B}_{12} \mathrm{H}_{12}$ was detected in a partially desorbed $2 \mathrm{NaBH}_{4}+\mathrm{MgH}_{2}$ sample (following $2 \mathrm{~h}$ at $450{ }^{\circ} \mathrm{C}$ ) and in the final products of the decomposition reaction by both direct comparison with the ${ }^{11} \mathrm{~B}\left\{{ }^{1} \mathrm{H}\right\}$ NMR spectrum of pure $\mathrm{Na}_{2} \mathrm{~B}_{12} \mathrm{H}_{12}$ and by dynamic cross-polarization experiments [28].

Considering now the reverse hydrogenation reaction in the $\mathrm{Na}-\mathrm{Mg}-\mathrm{B}-\mathrm{H}$ system, it has been suggested that the hydrogenation of $2 \mathrm{NaH}-\mathrm{MgB}_{2}$ proceeds according to the following reaction [41]:

$$
2 \mathrm{NaH}+\mathrm{MgB}_{2}+4 \mathrm{H}_{2} \rightarrow 2 \mathrm{NaBH}_{4}+\mathrm{MgH}_{2}
$$

Further scrutiny of the process indicated that the absorption reaction does not occur in a single step. Nwakwuo et al. [49] and Pistidda et al. [50], respectively, characterized the uptake mechanism of 
ball-milled $2 \mathrm{NaH}-\mathrm{MgB}_{2}$ by using transmission electron microscopy (TEM) and in situ PXD. Under 50 bar of hydrogen, a new and unknown hydride phase was observed at $c a .280{ }^{\circ} \mathrm{C}$. This phase remained present in diffraction patterns up to $325{ }^{\circ} \mathrm{C}$ followed by the formation of $\mathrm{NaMgH}_{3}$ at about $330{ }^{\circ} \mathrm{C}$. At $380{ }^{\circ} \mathrm{C}$, crystals of $\mathrm{NaBH}_{4}$ appeared and grew (Figure 6). The effect of the $\mathrm{NaH}: \mathrm{MgB}_{2}$ ratio on hydrogen uptake in the system has since become evident [51]. Unlike the 2:1 $\mathrm{NaH}: \mathrm{MgB}_{2}$ hydrogenation reaction, the only crystalline products of the hydrogenation of the 1:1 and 1:2 mixtures are $\mathrm{NaBH}_{4}$ and $\mathrm{MgH}_{2}$. Due to the reduced amount of $\mathrm{NaH}$ in the 1:2 system, the hydrogenation reaction proceeds towards the formation of $\mathrm{NaBH}_{4}$ and $\mathrm{MgH}_{2}$, completely consuming the $\mathrm{NaMgH}_{3}$ formed and avoiding the formation of a molten $\mathrm{NaH}-\mathrm{NaBH}_{4}$ phase.

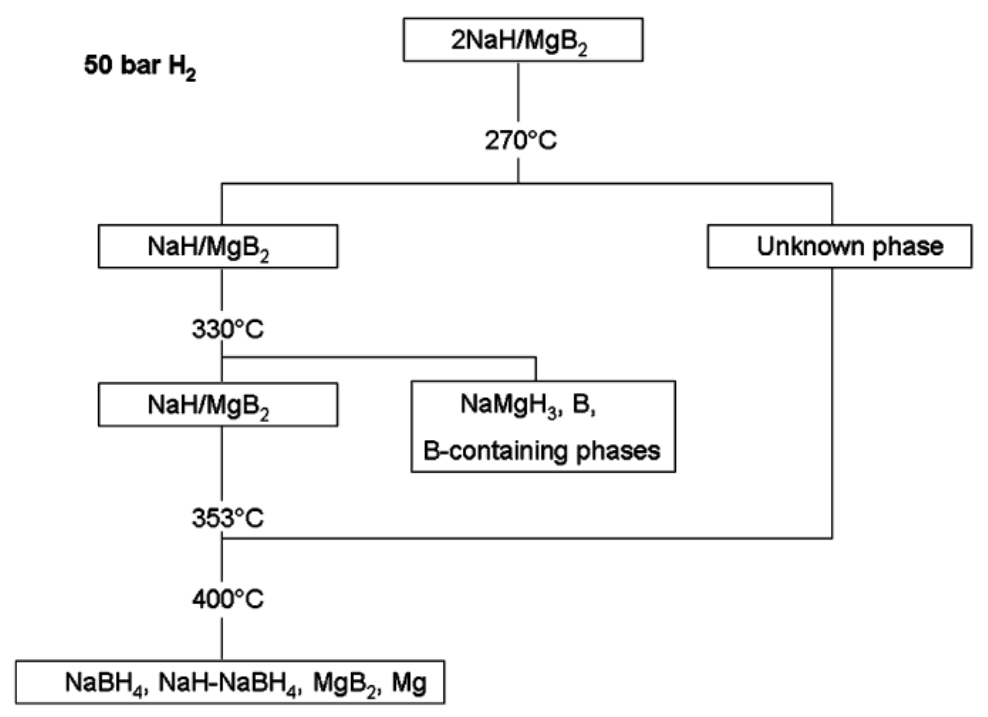

Figure 6. Scheme of the $2 \mathrm{NaH}+\mathrm{MgB}_{2}$ absorption reaction performed under $50 \mathrm{bar}_{2}$ [50]. Reprinted with permission from [50], copyright 2010 The American Chemical Society.

$\mathrm{NaBH}_{4}$ can also be synthesized from $\mathrm{NaH}$ and $\mathrm{MgB}_{2}$ under hydrogen by mechanochemical methods, but only partial hydrogenation is observed [52]. Although the formation of $\mathrm{NaBH}_{4}$ was experimentally observed by ex-situ ${ }^{11} \mathrm{~B}$ magic angle spinning (MAS) NMR under 1 bar of $\mathrm{H}_{2}$ with a milling speed of $300 \mathrm{rpm}$, even at 120 bar $\mathrm{H}_{2} / 550 \mathrm{rpm}$ the yield of $\mathrm{NaBH}_{4}$ was only $14 \mathrm{wt} \%$ (by PXD). Moreover, IR spectroscopy confirmed $\mathrm{MgH}_{2}$ in the milling products.

Hence, the above examples demonstrate that the dehydrogenation thermodynamics of $\mathrm{NaBH}_{4}$ are significantly improved by adding $\mathrm{MgH}_{2}$ and that re-hydrogenation is possible. To obtain improvements in release kinetics and/or achieve dehydrogenation temperatures below $400{ }^{\circ} \mathrm{C}$, approaches such as catalytic doping and nanoconfinement have been attempted for the $\mathrm{Na}-\mathrm{Mg}-\mathrm{B}-\mathrm{H}$ system just as with $\mathrm{NaBH}_{4}$ itself. $5 \mathrm{~mol} \% \mathrm{TiF}_{3}$ doping reduces the dehydrogenation temperature of the $2 \mathrm{NaBH}_{4}-\mathrm{MgH}_{2}$ system by $100{ }^{\circ} \mathrm{C}$ [41]. Moreover, $\mathrm{TiF}_{3}$ doped $2 \mathrm{NaBH}_{4}-\mathrm{MgH}_{2}$ can be rehydrogenated up to 5.89 wt $\%$ hydrogen within $12 \mathrm{~h}$ at $600{ }^{\circ} \mathrm{C}$ and $4 \mathrm{MPa} \mathrm{H}_{2} . \mathrm{NaBH}_{4}$ and $\mathrm{MgH}_{2}$ are the clearly observed re-hydrogenation products by PXD. Of several other additives (fluorides, chlorides and hydroxides), the most promising would appear to be $\mathrm{MgF}_{2}$ [8]. The $\mathrm{MgF}_{2}$ reduces the $\mathrm{NaBH}_{4}$ decomposition temperature by $30{ }^{\circ} \mathrm{C}$ and the desorption enthalpy by $2 \mathrm{~kJ} \cdot \mathrm{mol}^{-1}$. The rate constant for desorption (fitted to a modified Avrami-Erofeev equation over the isothermal region) increases by a factor of 3.2 when $\mathrm{MgF}_{2}$ is added. 
Perhaps rather unexpectedly, short-term exposure to a moist atmosphere appears to have a positive effect on the desorption reaction of the $2 \mathrm{NaBH}_{4}+\mathrm{MgH}_{2}$ mixture [53]. The as-milled mixture desorbs $3.4 \mathrm{wt} \%$ of hydrogen at $450{ }^{\circ} \mathrm{C}$, whereas $7.8 \mathrm{wt} \%$ of hydrogen is desorbed from the milled sample after $2 \mathrm{~h}$ of air exposure followed by drying. In this latter case, the final products are $\mathrm{MgB}_{2}$ and $\mathrm{NaH}$ (in addition to some $\mathrm{NaOH}$ ) whereas in the former, partial dehydrogenation yields $\mathrm{NaBH}_{4}$ and $\mathrm{Mg}$. Further investigation showed that the chemical state of the reactants is unchanged after exposure, but significant microstructural and morphological differences were revealed by Rietveld analysis and scanning electron microscope (SEM) characterization of the starting materials. It seems that the exposure of the $2: 1 \mathrm{NaBH}_{4}: \mathrm{MgH}_{2}$ system to moisture creates a scenario where the $\mathrm{MgH}_{2}$ remains solid whereas the $\mathrm{NaBH}_{4}$ forms a slurry that "wets" the surface of the $\mathrm{MgH}_{2}$ particles (protecting the $\mathrm{MgH}_{2}$ from reaction with air). The intimate interfacial contact is maintained in the solid state during the subsequent drying procedure facilitating dehydrogenation.

The effects of nanoconfinement have been evaluated against physically nanostructured mixtures by melt infiltration of $\mathrm{NaBH}_{4}-\mathrm{MgH}_{2}$ into mesoporous SBA-15 ( $\mathrm{NbF}_{5}$ was used as a catalyst in both cases) [54]. The thermal desorption profile of $2 \mathrm{NaBH}_{4}+\mathrm{MgH}_{2}$ shows two peaks at $c a .300{ }^{\circ} \mathrm{C}$ and $410{ }^{\circ} \mathrm{C}$, respectively. When $0.05 \mathrm{~mol}$ of $\mathrm{NbF}_{5}$ is added, the desorption profile of the mixture displays three peaks centered at $\mathrm{ca} .200{ }^{\circ} \mathrm{C}, 300{ }^{\circ} \mathrm{C}$, and $400{ }^{\circ} \mathrm{C}$, respectively. The comparison of the two traces suggests that the $\mathrm{NbF}_{5}$ additive actively alters the dehydrogenation process in the $2 \mathrm{NaBH}_{4}+\mathrm{MgH}_{2}$ system. If the same hydrides are nanoconfined $\left(2 \mathrm{NaBH}_{4}+\mathrm{MgH}_{2}+0.05\right.$ mol NbF 5 confined into SBA-15), three desorption peaks occur at $134{ }^{\circ} \mathrm{C}, 323{ }^{\circ} \mathrm{C}$ and $354{ }^{\circ} \mathrm{C}$, respectively. The changes in the desorption temperatures suggests that different reaction processes again occur in the nanoconfined-catalyzed material. Although Si-containing phases in the dehydrogenation product suggest that SBA-15 cannot be treated as an inert host, only hydrogen is observed as an evolved gas. The results indicate that favorable synergic effects between nanoconfinement and catalysis may exist for the $\mathrm{Na}-\mathrm{Mg}-\mathrm{B}-\mathrm{H}$ system as have been observed for $\mathrm{NaBH}_{4}$ itself. The reasons for these phenomena require further investigation.

\subsubsection{Fluoride Destabilization}

Despite improvements in performance over pristine $\mathrm{NaBH}_{4}$, destabilized systems such as those in Section 3.3.1 have been unable to achieve gravimetric hydrogen capacities on a level with theoretical maxima. Given that the melting point of the decomposition product, $\mathrm{Na}$, is $\sim 371 \mathrm{~K}$ [55] and that molten Na may serve as an effective mass-transfer medium to promote atomic/ionic diffusion, one possible reason for this under-performance in the $\mathrm{Na}-\mathrm{Mg}-\mathrm{B}-\mathrm{H}$ system is that a melting-induced phenomenon takes place during dehydrogenation. As a result, the local stoichiometry and homogeneity of the mixture may be disrupted, hindering rehydrogenation to $\mathrm{NaBH}_{4}$. Alternatively, hydrogen released during dehydrogenation may transport $\mathrm{Na}$ away from the reaction mixture in the liquid and/or vapor phase. To prevent such eventualities, Na may be confined to the solid state (together with boron) by using certain additives such as metal fluorides. On the one hand, boron, the decomposition product of $\mathrm{NaBH}_{4}$ can be stabilized by other metals to form borides while on the other, $\mathrm{Na}$ forms $\mathrm{NaF}$ with a significantly elevated melting point compared to Na metal (i.e., a more than 3-fold increase; $1263 \mathrm{~K}$ ) [56].

In addition, and also important, the thermodynamic and kinetic behaviour of $\mathrm{NaBH}_{4}$ dehydrogenation itself may be tuned through the substitution of fluorine for hydrogen since $\mathrm{H}^{-}$and $\mathrm{F}^{-}$have similar 
ionic radii [57]. For example, a recent study on the $\mathrm{NaBH}_{4}-\mathrm{NaBF}_{4}$ system showed that hydrogen-fluorine exchange took place in a temperature range of $200-215^{\circ} \mathrm{C}$, leading to a new rock salt-type compound with idealized composition $\mathrm{NaBF}_{2} \mathrm{H}_{2}$ [58]. After further heating, the fluorine substituted compound becomes X-ray amorphous and decomposes to $\mathrm{NaF}$ at $310{ }^{\circ} \mathrm{C}$. In particular, the $\mathrm{NaBH}_{4}-\mathrm{NaBF}_{4}$ composite decomposes at lower temperatures $\left(T=300{ }^{\circ} \mathrm{C}\right)$ compared to $\mathrm{NaBH}_{4}\left(T=476{ }^{\circ} \mathrm{C}\right)$ and retains $30 \%$ of the hydrogen storage capacity after three hydrogen release and uptake cycles compared to $6 \%$ for $\mathrm{NaBH}_{4}$.

Two new systems based on $2 \mathrm{NaF}+\mathrm{MgB}_{2}+0.05 \mathrm{TiF}_{3}$ (referred to here as the "Mg system") and $2 \mathrm{NaF}+\mathrm{AlB}_{2}+0.05 \mathrm{TiF}_{3}$ ("Al system") were investigated by employing a fluorine-hydrogen substitution strategy [59]. The hydrogenation of the $\mathrm{Mg}$ system yielded $\mathrm{NaBH}_{4}$ and $\mathrm{MgF}_{2}$, which can be dehydrogenated to $\mathrm{NaMgF}_{3}$ and $\mathrm{MgB}_{2}$. In contrast, the hydrogenation of the $\mathrm{Al}$ system yielded $\mathrm{NaBH}_{4}$ and $\mathrm{Na}_{3} \mathrm{AlF}_{6}$, which was dehydrogenated to $\mathrm{NaF}$ and $\mathrm{AlB}_{2}$. These processes are therefore reversible and compared to pure $\mathrm{NaBH}_{4}$ a significant kinetic and thermodynamic destabilisation with respect to the hydrogenation and dehydrogenation is achieved (Figure 7). The reversible hydrogen storage capacity reached $3.8 \mathrm{wt} \%$ and $2.5 \mathrm{wt} \%$ for the $\mathrm{Mg}$ and $\mathrm{Al}$ systems, respectively.

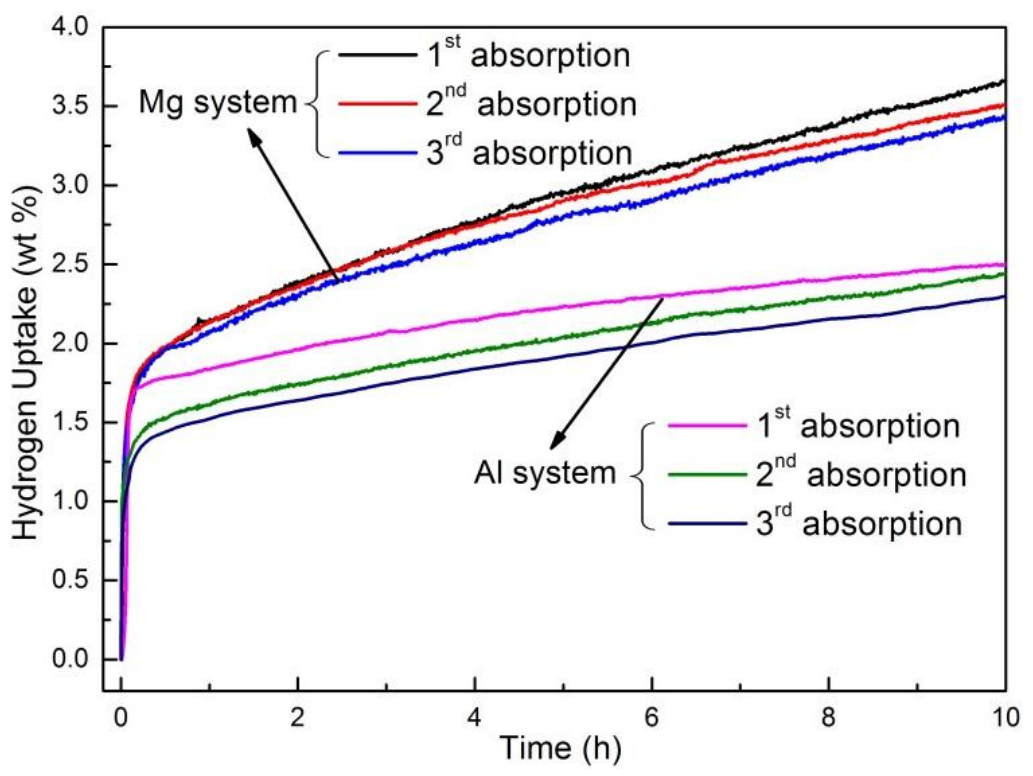

Figure 7. Hydrogenation and dehydrogenation curves for the $2 \mathrm{NaF}-\mathrm{MgB} 2\left(\mathrm{AlB}_{2}\right)-0.05 \mathrm{TiF}_{3}$ systems on cycling at $500{ }^{\circ} \mathrm{C}$ and $6 \mathrm{MPa}$ hydrogen pressure [59]. Reproduced from [59] by permission of The Royal Society of Chemistry.

Combining $\mathrm{NaBH}_{4}$ and $\mathrm{ZnF}_{2}$ generates hydrogen by forming $\mathrm{NaBF}_{4}$ with an onset temperature below $100{ }^{\circ} \mathrm{C}$ with favorable kinetics [60]. However, a small amount of $\mathrm{B}_{2} \mathrm{H}_{6}$ is released and the reversibility of the system is unknown. Studies of the effect of transition metal fluorides on the decomposition of $\mathrm{NaBH}_{4}$ by reacting $\mathrm{NaBH}_{4}$ with $\mathrm{TiF}_{3}$ mechanochemically, $\mathrm{MnF}_{3}$ or $\mathrm{FeF}$ revealed that $\mathrm{NaBF}_{4}$ was among the products in all cases [61]. Analysis of ${ }^{11} \mathrm{~B}-\mathrm{NMR}$ spectra gave $\mathrm{NaBF}_{4}: \mathrm{NaBH}_{4}$ ratios of 1:150, 1:40 and 1:10 for the Ti-, Mn- and Fe-containing systems respectively. The hydrogen release in the $\mathrm{NaBH}_{4}-\mathrm{MnF}_{3}$ system began at $130{ }^{\circ} \mathrm{C}$ while $\mathrm{FeF}_{3}$ decreased the onset temperature to $161{ }^{\circ} \mathrm{C}$ and $\mathrm{TiF}_{3}$ to $200{ }^{\circ} \mathrm{C}$. $\mathrm{TiF}_{3}$ reacted completely with $\mathrm{NaBH}_{4}$ below $320{ }^{\circ} \mathrm{C}$. All these $3 \mathrm{~d}$ transition metal fluoride containing materials display negligible emissions of diborane species. 
Both dehydrogenation and hydrogenation can be improved by adding rare earth fluorides ( $\mathrm{LnF}_{3}$, $\mathrm{Ln}=\mathrm{Nd}$, Y, La, Ho) [62-65]. The $3 \mathrm{NaBH} 4 / \mathrm{LnF}_{3}$ composites release hydrogen between $400{ }^{\circ} \mathrm{C}$ and $450{ }^{\circ} \mathrm{C}$, which is lower than that of pure $\mathrm{NaBH}_{4}$. Approximately $3 \mathrm{wt} \%$ hydrogen can be cycled in these systems. By analogy to the destabilization mechanisms proposed for other metal fluoride "composite" systems, the improvement can be attributed to the formation of borides according to the following reactions:

$$
\mathrm{LnF}_{3}+3 \mathrm{NaBH}_{4} \rightarrow 3 \mathrm{NaF}+3 / x \mathrm{LnB}_{x}+(1-3 / x) \mathrm{LnH}_{y}+(12-y+3 y / x) / 2 \mathrm{H}_{2}
$$

For example, dehydrogenation commences at $413{ }^{\circ} \mathrm{C}$ under $0.1 \mathrm{MPa}$ Ar for the $3 \mathrm{NaBH}_{4} / \mathrm{NdF}_{3}$ system [62]. PXD revealed that $\mathrm{NdB}_{6}, \mathrm{Nd}_{2} \mathrm{H}_{5}$ and $\mathrm{NaF}$ formed on decomposition. The process is pseudo-reversible, producing $\mathrm{NaBH}_{4}$ and $\mathrm{NaNdF}_{4}$ on hydrogenation. Similarly, dehydrogenation of $3 \mathrm{NaBH}_{4} / \mathrm{YF}_{3}$ starts at $423{ }^{\circ} \mathrm{C}$ but with a higher mass loss of $4.12 \mathrm{wt} \%$ (given the lower atomic mass of $\mathrm{Y}$ over $\mathrm{Nd}$ ) [63]. PXD of the dehydrogenated products reveals $\mathrm{NaF}, \mathrm{YB}_{4}$ and $\mathrm{YH}_{2}$ are formed and re-hydrogenation leads to $\mathrm{NaBH}_{4}$ and $\mathrm{NaYF}_{4}$ by analogy to the neodymium system.

The above shows that the products from $\mathrm{NaBH}_{4}$ dehydrogenation can be stabilized simultaneously by introducing both fluorine and metals, hence effectively destabilizing $\mathrm{NaBH}_{4}$. Although the conditions required for dehydrogenation and rehydrogenation in these systems are still too extreme for practical applications, the improvement in uptake and release provides the basis for a broader destabilization strategy.

\subsection{Chemical Modification}

\subsubsection{Combination of Protic and Hydridic H Atoms}

It is well known that hydrogen exists in a partially negatively charged state $\left(\mathrm{H}^{\delta^{-}}\right)$in complex hydrides such as $\mathrm{NaBH}_{4}$, whereas it is partially positively charged $\left(\mathrm{H}^{\delta+}\right)$ in nitrogen containing compounds such as $\mathrm{LiNH}_{2}$. Given the repulsive potential between two positively charged $\left(\mathrm{H}^{\delta^{+}} / \mathrm{H}^{\delta^{+}}\right)$ or two negatively charged $\left(\mathrm{H}^{\delta^{-}} / \mathrm{H}^{\delta^{-}}\right)$species, there are relatively high energy barriers to the conversion of either $\mathrm{H}^{\delta-}$ or $\mathrm{H}^{\delta+}$ pairs to neutral $\mathrm{H}_{2}$. This contrasts markedly with the ease of combining $\mathrm{H}^{\delta^{-}}$ and $\mathrm{H}^{\delta+}$ [66]. These observations suggest that the reaction kinetics of $\mathrm{H}_{2}$ formation can be enhanced by inducing $\mathrm{H}^{+}$and $\mathrm{H}^{-}$mobility in compounds with suitable structures. Thus, it is of particular interest to consider the range of $\mathrm{H}^{\delta+}$-rich compounds that could be combined with $\mathrm{NaBH}_{4}$ to improve dehydrogenation.

Chater et al. [67] found a new cubic phase in the $\mathrm{NaNH}_{2}-\mathrm{NaBH}_{4}$ system with composition $\mathrm{Na}_{2} \mathrm{BNH}_{6}$ $\left(a \approx 4.7 \AA\right.$ ) at $190{ }^{\circ} \mathrm{C}$. Hydrogen release initiates at $c a .290{ }^{\circ} \mathrm{C}$ in $\mathrm{Na}_{2} \mathrm{BNH}_{6}$ and peaks at $\sim 350{ }^{\circ} \mathrm{C}$. Ammonia is also released, constituting approximately $7 \mathrm{wt} \%$ of the total desorbed gas. The decomposition products are reported to be $\mathrm{NaH}, \mathrm{Na}$ and an amorphous unidentified white solid. In fact, $\mathrm{Na}_{2} \mathrm{BNH}_{6}$ releases hydrogen while molten between $300{ }^{\circ} \mathrm{C}$ and $400{ }^{\circ} \mathrm{C}$ yielding $\mathrm{NaH}, \mathrm{Na}$ and a grey amorphous powder [68]. On addition of excess amide $\left(\geq 2: 1 \mathrm{NaNH}_{2}: \mathrm{NaBH}_{4}\right), \mathrm{Na}_{3} \mathrm{BN}_{2}$ becomes the sole product.

Another new phase in the $\mathrm{NaNH}_{2}-\mathrm{NaBH}_{4}$ system, $\mathrm{Na}_{3}\left(\mathrm{NH}_{2}\right)_{2} \mathrm{BH}_{4}$, is attainable by ball milling (at a molar ratio of 2:1) [69]. Thermal analysis shows that decomposition occurs in two main stages: (i) dehydrogenation below $400{ }^{\circ} \mathrm{C}$ to form $\mathrm{Na}_{3} \mathrm{BN}_{2}$ (6.85 wt\%); and (ii) decomposition of $\mathrm{Na}_{3} \mathrm{BN}_{2}$ above $400{ }^{\circ} \mathrm{C}$ to produce $\mathrm{Na}, \mathrm{B}$, and $\mathrm{N}_{2}$ according to the following reactions: 


$$
\mathrm{Na}_{3}\left(\mathrm{NH}_{2}\right)_{2} \mathrm{BH}_{4} \rightarrow \mathrm{Na}_{3} \mathrm{BN}_{2}+4 \mathrm{H}_{2} \rightarrow 3 \mathrm{Na}+\mathrm{B}+\mathrm{N}_{2}+4 \mathrm{H}_{2}
$$

Another example in terms of "protic" species that could be combined with borohydrides, is that of hydroxide. Drozd et al. [70] investigated the hydrogen-generating reaction between $\mathrm{NaBH}_{4}$ and $\mathrm{Mg}(\mathrm{OH})_{2}$, and found that reaction rate depends tremendously on the homogeneity and/or particle size of the reactants. PXD and Raman spectroscopy reveal that mechanically activated mixtures of $\mathrm{NaBH}_{4}$ and $\mathrm{Mg}(\mathrm{OH})_{2}$ react yielding $\mathrm{MgO}$ as the only crystalline phase between $240{ }^{\circ} \mathrm{C}$ and $318{ }^{\circ} \mathrm{C}$. Ball milled $\mathrm{NaBH}_{4}-2 \mathrm{Mg}(\mathrm{OH})_{2}$ mixtures release hydrogen in one exothermic reaction, with an onset temperature of $240{ }^{\circ} \mathrm{C}$ [71]. The estimated enthalpy for the reaction is $135.9 \mathrm{~kJ} \cdot \mathrm{mol}^{-1}$ and the dehydrogenation products contain $\mathrm{NaBO}_{2}$ and $\mathrm{MgO}$ [70]. Therefore, the following dehydrogenation reaction was proposed:

$$
\mathrm{NaBH}_{4}+2 \mathrm{Mg}(\mathrm{OH})_{2} \rightarrow \mathrm{NaBO}_{2}+2 \mathrm{MgO}+4 \mathrm{H}_{2} \quad 5.18 \mathrm{wt} \% ; \Delta H=-135.9 \mathrm{~kJ} \cdot \mathrm{mol}^{-1}
$$

The various studies above show that the dehydrogenation of $\mathrm{NaBH}_{4}$ can be improved by reaction with $\mathrm{H}^{\delta+}$-containing starting materials (such as $\mathrm{NaNH}_{2}$ or $\mathrm{Mg}(\mathrm{OH})_{2}$ ) based on the premise of favorable $\mathrm{H}^{+}-\mathrm{H}^{-}$interactions. However, the dehydrogenation reaction of these systems can be exothermic, which clearly introduces substantial challenges in terms of cycling or regeneration.

\subsubsection{Bimetallic Borohydrides}

Nakamori et al. [72,73] theoretically and experimentally found that a clear correlation exists between the thermodynamic stability of metal borohydrides and the Pauling electronegativity of the respective metal cations (Figure 8). It was thus proposed that the dehydrogenation temperature of $\mathrm{M}\left(\mathrm{BH}_{4}\right)_{n}$, where $\mathrm{M}$ is a metal cation of valence $n$, decreases linearly with the increasing electronegativity of $\mathrm{M}$. Hence one of the approaches to adjust the dehydrogenation thermodynamics of metal borohydrides is to substitute an alkali or alkaline earth metal, for example, by another metal with higher electronegativity.

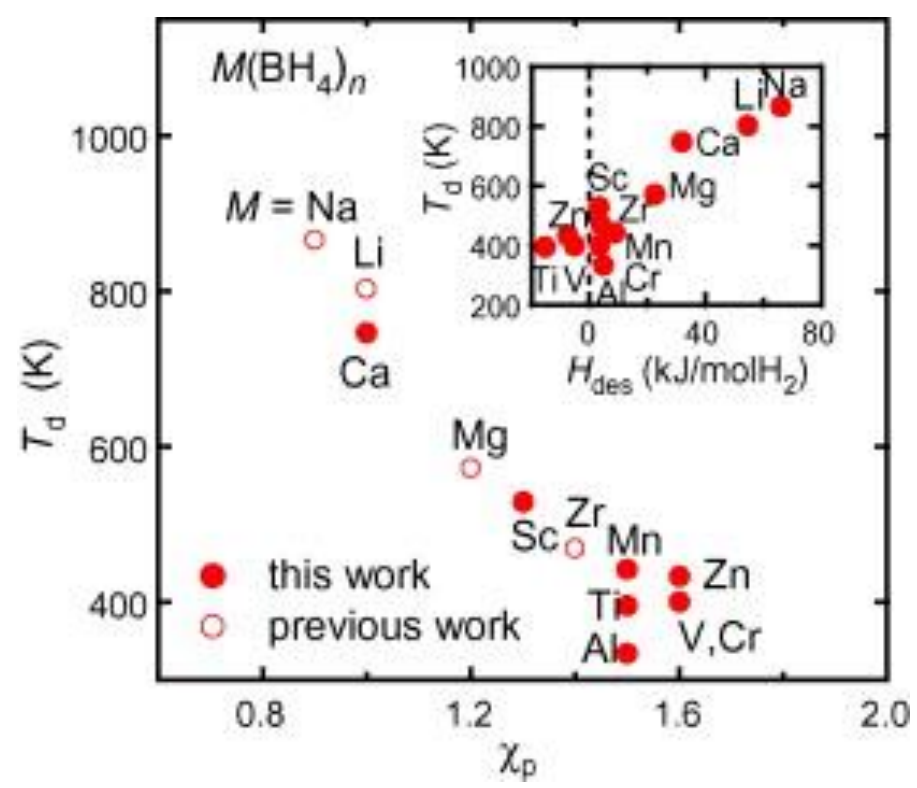

Figure 8. The dehydrogenation temperature, $T_{\mathrm{d}}$ as a function of the Pauling electronegativity $\chi_{\mathrm{p}}$ for selected metals. The inset shows the correlation between $T_{\mathrm{d}}$ and estimated $H_{\mathrm{des}}$ for the desorption reaction [73]. Reprinted with permission from [73], copyright 2007 Elsevier. 
$\mathrm{NaK}\left(\mathrm{BH}_{4}\right)_{2}$ was synthesized by mechanical milling of $\mathrm{NaBH}_{4}$ and $\mathrm{KBH}_{4}$ in a 1:1 ratio [74]. The new phase forms with a rhombohedral structure (tentatively space group R3), but in situ PXD indicated it was metastable, decomposing to the starting materials $\mathrm{NaBH}_{4}$ and $\mathrm{KBH}_{4}$ after $14 \mathrm{~h}$ at room temperature. A more common method for the synthesis of bimetallic sodium borohydrides is by solid or solution-state metathesis [75]:

$$
x \mathrm{NaBH}_{4}+\mathrm{MCl}_{y} \rightarrow \mathrm{Na} x-y \mathrm{M}\left(\mathrm{BH}_{4}\right)_{x}+y \mathrm{NaCl}
$$

where $\mathrm{M}$ is an alkali metal, alkaline earth metal, transition metal or lanthanide. For example, the new bimetallic borohydride $\mathrm{NaSc}\left(\mathrm{BH}_{4}\right)_{4}$ was synthesised by ball-milling mixtures of sodium borohydride and $\mathrm{ScCl}_{3}$ [76]. The structure of $\left.\mathrm{NaSc}_{(\mathrm{BH}}\right)_{4}$ (orthorhombic space group Cmcm $a=8.170(2) \AA$, $b=11.875(3) \AA, c=9.018(2) \AA$ ) consists of isolated scandium tetraborohydride tetrahedral anions, $\left[\mathrm{Sc}\left(\mathrm{BH}_{4}\right)_{4}\right]^{-}$, located inside slightly distorted trigonal $\mathrm{Na} 6$ prisms (each second prism is empty) (Figure 9). $\mathrm{Na}^{+}$is surrounded by six $\mathrm{BH}_{4}{ }^{-}$tetrahedra in almost regular octahedral coordination with a $(6+12)$-fold coordination of $\mathrm{H}$ to $\mathrm{Na}$. $\mathrm{NaSc}\left(\mathrm{BH}_{4}\right)_{4}$ melts at $\sim 137{ }^{\circ} \mathrm{C}$ subsequently releasing hydrogen in two steps between $167-217{ }^{\circ} \mathrm{C}$ and $222-267{ }^{\circ} \mathrm{C}$. Scandium boride $\mathrm{ScB}_{x}$ is tentatively identified as one of the decomposition products.

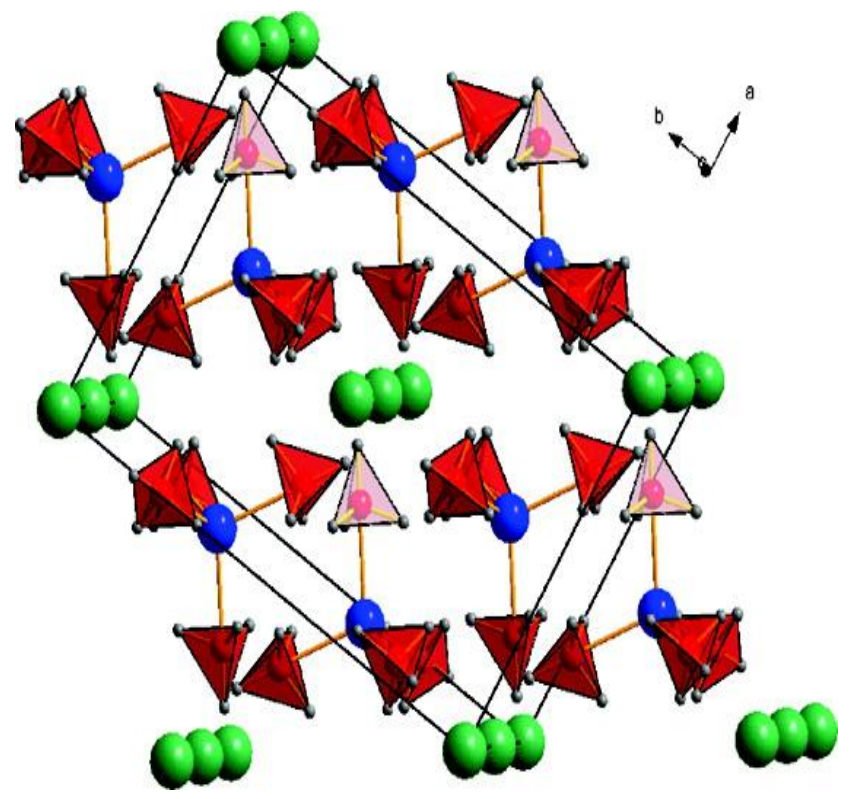

Figure 9. Crystal structure of $\mathrm{NaSc}\left(\mathrm{BH}_{4}\right)_{4}$ showing the coordination of $\mathrm{Sc}$ atoms (blue) by $\mathrm{BH}_{4}$ tetrahedra (red); $\mathrm{Na}$ atoms are in green [76]. Reprinted with permission from [76], copyright 2010 The American Chemical Society.

$\mathrm{NaZn}\left(\mathrm{BH}_{4}\right)_{3}$ can be synthesized by ball milling $\mathrm{NaBH}_{4}$ and $\mathrm{ZnCl}_{2}$ in a 3:1 molar ratio and in fact if the starting ratios are varied (e.g., 2:1, 4:1) mixtures of $\mathrm{NaZn}_{2}\left(\mathrm{BH}_{4}\right)_{5}$ and $\mathrm{NaZn}\left(\mathrm{BH}_{4}\right)_{3}$ are obtained, indicating competitive reactions [77]. $\mathrm{NaZn}\left(\mathrm{BH}_{4}\right)_{3}$ (monoclinic space group $P 2{ }_{1} / c$; Figure 10) consists of $1 \mathrm{D}$ anionic $\left[\left\{\mathrm{Zn}\left(\mathrm{BH}_{4}\right)_{3}\right\}_{n}\right]^{n^{-}}$chains with tetrahedrally coordinated $\mathrm{Zn}$ atoms, which are connected in three dimensions through the $\mathrm{Na}^{+}$ions. $\mathrm{NaZn}_{2}\left(\mathrm{BH}_{4}\right)_{5}$ meanwhile, is unstable and slowly decomposes to $\mathrm{NaZn}\left(\mathrm{BH}_{4}\right)_{3}$ at room temperature. The structure of $\mathrm{NaZn}_{2}\left(\mathrm{BH}_{4}\right)_{5}$ (also monoclinic space group $P 2_{1} / c$ ) consists of $\mathrm{Na}^{+}$cations and isolated complex dimeric $\left[\mathrm{Zn}_{2}\left(\mathrm{BH}_{4}\right)_{5}\right]^{-}$anions in which trigonal planar centers of $\mathrm{Zn}$ are each coordinated to one bridging and two terminal $\mathrm{BH}_{4}$ groups. 


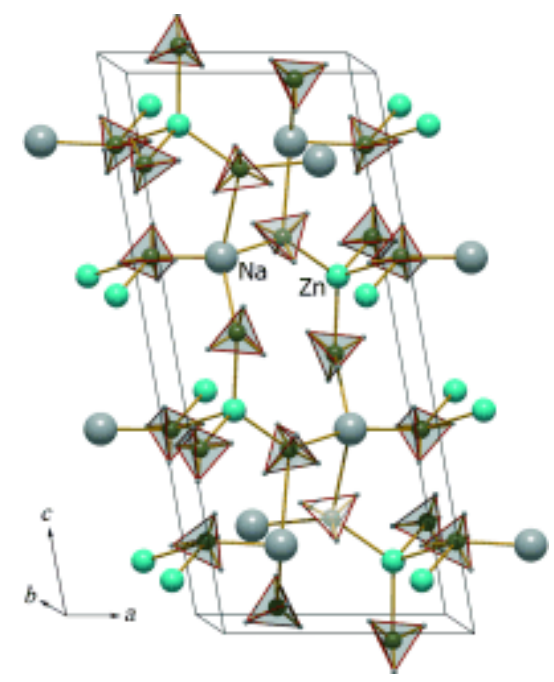

Figure 10. Crystal structure of $\mathrm{NaZn}\left(\mathrm{BH}_{4}\right)_{3} ; \mathrm{Zn}$ atoms in blue, $\mathrm{B}$ in brown, $\mathrm{Na}$ in dark grey, and $H$ in light grey [77]. Reprinted with permission from [77], copyright 2009 John Wiley \& Sons.

Pure $\mathrm{NaZn}\left(\mathrm{BH}_{4}\right)_{3}$, synthesized by a solution route, releases hydrogen coupled with borane and diborane $\mathrm{BH}_{3}$, and $\mathrm{B}_{2} \mathrm{H}_{6}$, giving a total weight loss of $29 \mathrm{wt} \%$ between $80{ }^{\circ} \mathrm{C}$ and $200{ }^{\circ} \mathrm{C}$ [78]. Nanoconfinement of $\mathrm{NaZn}\left(\mathrm{BH}_{4}\right)_{3}$ in SBA-15 however leads to borane-free hydrogen evolution across a temperature range of $50-150{ }^{\circ} \mathrm{C}$ from onset to completion. The activation energy for dehydrogenation was reduced to $38.9 \mathrm{~kJ} \cdot \mathrm{mol}^{-1}$ in the nanoconfined solid; a reduction of $5.3 \mathrm{~kJ} \cdot \mathrm{mol}^{-1}$ compared to that of bulk $\mathrm{NaZn}\left(\mathrm{BH}_{4}\right)_{3}$.

The novel mixed-cation mixed-anion borohydride chloride, $\mathrm{NaY}\left(\mathrm{BH}_{4}\right)_{2} \mathrm{Cl}_{2}$ was prepared by mechanochemical synthesis from $\mathrm{NaBH}_{4}-\mathrm{YCl}_{3}$ mixtures followed by annealing (with $\mathrm{Na}_{3} \mathrm{YCl}_{6}$ and $\mathrm{Na}\left(\mathrm{BH}_{4}\right)_{1-x} \mathrm{Cl}_{x}$ as impurity phases) [79]. The structure of $\mathrm{NaY}\left(\mathrm{BH}_{4}\right)_{2} \mathrm{Cl}_{2}$ is pseudo-orthorhombic (monoclinic space group $\mathrm{P} 2 / \mathrm{c}$ ) and isotypic with the high temperature polymorph of $\mathrm{NaYCl}_{4}$. The borohydride chloride is comprised of edge- and corner-sharing yttrium-centered and sodium-centered octahedra ( $\mathrm{Y}$ is coordinated by four $\mathrm{Cl}$ and two $\mathrm{BH}_{4}$ ligands, whereas $\mathrm{Na}$ is coordinated by two $\mathrm{Cl}$ and four $\mathrm{BH}_{4}$ ligands; Figure 11).

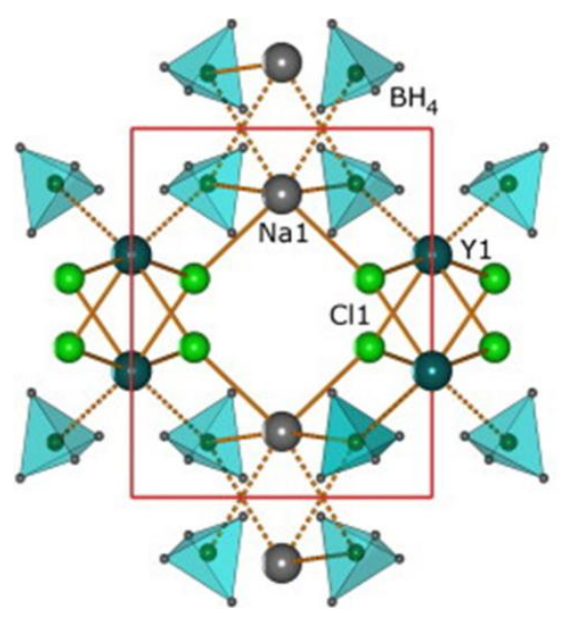

Figure 11. Crystal structure of $\mathrm{NaY}\left(\mathrm{BH}_{4}\right)_{2} \mathrm{Cl}_{2}$ at $T \sim 230{ }^{\circ} \mathrm{C}$ [79]. Reprinted from [79] with permission from the International Association of Hydrogen Energy. 
In situ synchrotron PXD studies show that $\mathrm{NaY}\left(\mathrm{BH}_{4}\right)_{2} \mathrm{Cl}_{2}$ decomposes to $\mathrm{Na}_{3} \mathrm{YCl}_{6}$ with amorphous yttrium borides the likely other products. The decomposition is an endothermic process that occurs at ca. $300^{\circ} \mathrm{C}$ and the observed thermogravimetric analysis (TGA) mass losses suggest that no significant amount of diborane is released during the decomposition.

The thermal decomposition of ball milled mixtures of $\mathrm{NaBH}_{4}$ with the chlorides of the $3 \mathrm{~d}$ transition metals and cadmium (M) has been systematically investigated (Table 2) [75]. In contrast to predictions from theory, which in many cases have suggested the formation of mixed metal borohydrides [80], all the above reactions involve the substitution of $\mathrm{BH}_{4}{ }^{-}$by $\mathrm{Cl}^{-}$and the formation of cubic NaCl-type $\mathrm{Na}\left(\mathrm{BH}_{4}\right)_{1-x} \mathrm{Cl}_{x}$ solid solutions (with presumed amorphous transition metal borides as the other product in most cases). Samples containing $\mathrm{Sc}, \mathrm{Mn}$ and $\mathrm{Zn}$ release $<0.05 \mathrm{~mol}$ gas per mol of $\mathrm{Na}$ atoms during milling whereas the remainder of the $3 \mathrm{~d}$ transition metal samples release $c a .1 \mathrm{~mol}$ of gas per mol of $\mathrm{Na}$ atoms with $\mathrm{Fe}$ - and Co-containing samples reaching maximum gas release most quickly (after $1 \mathrm{~h}$ ).

Table 2. Structural and thermal decomposition parameters for ball milled $\mathrm{NaBH}_{4}+\mathrm{MCl}_{n}$ powders (mixed in in 3:1 $\left(\mathrm{MCl}_{2}\right)$ or 4:1 $\left(\mathrm{MCl}_{3}\right)$ ratios). Note: the parameters for $\mathrm{M}=\mathrm{Sc}$ were not reported [75]. Reprinted from [75] with permission from Elsevier; copyright 2012.

\begin{tabular}{ccccc}
\hline Starting reagents & $\begin{array}{c}\mathbf{N a}\left(\mathbf{B H}_{4}\right)_{1-\boldsymbol{x}} \mathbf{C l}_{\boldsymbol{x}} \text { cell } \\
\text { parameter, } \boldsymbol{a} / \mathbf{A}\end{array}$ & $\mathbf{C l ~ c o n t e n t , \boldsymbol { x }}$ & Decomposition $\boldsymbol{T} /{ }^{\circ} \mathbf{C}$ & $\begin{array}{c}\text { Mass loss at } \\
\boldsymbol{T} \leq \mathbf{6 0 0}{ }^{\circ} \mathbf{C} / \mathbf{w t} \boldsymbol{\%}\end{array}$ \\
\hline $\mathrm{NaCl}$ only & $5.6400(5)$ & 1 & - & - \\
$\mathrm{NaBH}_{4} / \mathrm{TiCl}_{2}$ & $5.7685(3)$ & 0.71 & 401 & 2.7 \\
$\mathrm{NaBH}_{4} / \mathrm{VCl}_{3}$ & $5.7306(4)$ & 0.79 & 391 & 3.0 \\
$\mathrm{NaBH}_{4} / \mathrm{CrCl}_{3}$ & $5.7383(2)$ & 0.77 & 397 & - \\
$\mathrm{NaBH}_{4} / \mathrm{MnCl}_{2}$ & $5.7863(4)$ & 0.68 & 146 & 5.7 \\
$\mathrm{NaBH}_{4} / \mathrm{FeCl}_{3}$ & $5.7407(4)$ & 0.77 & 397 & 0.2 \\
$\mathrm{NaBH}_{4} / \mathrm{CoCl}_{2}$ & $5.8011(3)$ & 0.65 & 413 & 3.6 \\
$\mathrm{NaBH}_{4} / \mathrm{NiCl}_{2}$ & $5.7837(9)$ & 0.68 & 391 & 4.0 \\
$\mathrm{NaBH}_{4} / \mathrm{CuCl}_{2}$ & $5.7801(3)$ & 0.69 & 343 & 3.7 \\
$\mathrm{NaBH}_{4} / \mathrm{ZnCl}_{2}$ & $5.6576(2)$ & 0.92 & 103 & 21.7 \\
$\mathrm{NaBH}_{4} / \mathrm{CdCl}_{2}$ & $5.7572(8)$ & 0.74 & 521 & - \\
$\mathrm{NaBH}_{4}$ only & $6.13080(10)$ & 0 & - & - \\
\hline
\end{tabular}

In subsequent thermal desorption experiments, the maximum release temperature ranges from $103{ }^{\circ} \mathrm{C}(\mathrm{Zn})$ to $521{ }^{\circ} \mathrm{C}(\mathrm{Cd})$ and $\mathrm{NaBH}_{4}-\mathrm{NaCl}$ samples demonstrate decomposition at ca. $500{ }^{\circ} \mathrm{C}$, similar to pure $\mathrm{NaBH}_{4}$. That $\mathrm{Sc}, \mathrm{Mn}$, and $\mathrm{Zn}$ form other stable compounds in addition to $\left.\mathrm{Na}_{(\mathrm{BH}}\right)_{1-x} \mathrm{Cl}_{x}$ (e.g., $\mathrm{NaZn}\left(\mathrm{BH}_{4}\right)_{3}$ which decomposes between $92{ }^{\circ} \mathrm{C}$ and $112{ }^{\circ} \mathrm{C}$ ) explains the low decomposition temperatures observed (i.e., below $230{ }^{\circ} \mathrm{C}$ ). In fact, the trends in decomposition temperatures can be related to these compounds and to kinetic effects rather than to a systematic destabilisation of the $\mathrm{NaBH}_{4}$ cubic structure. $\mathrm{V}, \mathrm{Ni}$ and $\mathrm{Ti}$, for example, form borides, which can act as catalysts whereas for $\mathrm{Cu}$ and $\mathrm{Cd}$ the high desorption temperatures would indicate the presence of metallic $\mathrm{Cd}$ and $\mathrm{Cu}$, which have no beneficial effect on decomposition.

\section{Closing Remarks}

$\mathrm{NaBH}_{4}$ is undoubtedly a very interesting material for hydrogen storage due to its high hydrogen density (10.6 wt\%), low cost and relative air stability. However, the high dehydrogenation temperature, 
slow kinetics and poor reversibility are challenges that have to be overcome before the borohydride could be considered for practical applications. Several approaches to tackle both thermodynamic and kinetic issues have been employed ranging from catalysis through nano-engineering and additive destabilization to chemical modification. From the discussions in the sections above, it is apparent that each input can make a successful impact in terms of modifying thermodynamic stability, reducing dehydrogenation temperatures, improving equilibrium pressures, lowering activation energies or optimizing reversible capacity. While sorption kinetics can be enhanced, catalysis alone is not capable of altering the thermodynamics of uptake and release and hence reversibility. Various chemical destabilization, doping and "composite" approaches confront these issues via creating alternative reaction pathways for uptake and release. These strategies can either increase of decrease gravimetric capacity depending on the "activity" of the added components to making (and breaking) bonds with hydrogen. So-called nano-engineering methods such as nanoconfinement or the formation of core-shell nanostructures can combine the benefits of catalysis and chemical modification, but often to the detriment of gravimetric capacity. The benefits and drawbacks of each approach relative to the hydrogen storage performance of $\mathrm{NaBH}_{4}$ itself are summarized in Table 3.

Table 3. Comparison of materials modification approaches relative to $\mathrm{NaBH}_{4}$ itself (where "+" signifies an improvement and "-" signifies a decline).

\begin{tabular}{cccccc}
\hline Strategy & $\boldsymbol{T}_{\mathbf{d}} \mathbf{a}^{\mathbf{a}}$ & Kinetics & $\mathbf{w t} \% \mathbf{H}_{\mathbf{2}} \mathbf{b}^{\mathbf{c}}$ & Cyclability & References \\
\hline Catalytic doping & + & + & - & + & {$[32,33]$} \\
Nano-confinement & + & + & - & + & {$[29,36-39]$} \\
$\mathrm{H}^{-}$destabilisation & + & + & + & + & {$[27,41-45]$} \\
$\mathrm{F}^{-}$destabilisation & + & + & - & + & {$[40,59-65]$} \\
$\mathrm{H}^{\delta+}-\mathrm{H}^{\delta-}$ "composites" & + & + & - & - & {$[66-71]$} \\
Bimetallic Na borohydrides & + & + & - & - & {$[74-80]$} \\
\hline
\end{tabular}

${ }^{\mathrm{a}}$ Dehydrogenation onset temperature; and ${ }^{\mathrm{b}}$ practically realizable gravimetric capacity.

Clearly, all these strategies demonstrably help overcome one or more of the limitations of pristine $\mathrm{NaBH}_{4}$ as a thermally-driven hydrogen store, but thus far, no modified materials can simultaneously meet all the major performance criteria required for mobile applications. The screening of more suitable catalysts and additives, developing new techniques to fabricate nanomaterials, discovering suitable lightweight mesoporous hosts, restricting loss of molten $\mathrm{Na}$ and greater understanding of the mechanisms involved in hydrogen release and uptake are some of the principal objectives towards making $\mathrm{NaBH}_{4}$-based systems viable. However, it may be a radically different approach in which $\mathrm{NaBH}_{4}$ is a component part that finally delivers a practical solution.

\section{Acknowledgments}

The research post for Jianfeng Mao has received funding from the European Union's Seventh Framework Programme (FP7/2007-2013) for the Fuel Cells and Hydrogen Joint Technology Initiative under Grant Agreement Number 303447. 


\section{Conflicts of Interest}

The authors declare no conflict of interest.

\section{References}

1. Schlapbach, L.; Züttel, A. Hydrogen-storage materials for mobile applications. Nature 2001, 414, 353-358.

2. Eberle, U.; Felderhoff, M.; Schüth, F. Chemical and physical solutions for hydrogen storage. Angew. Chem. Int. Ed. 2009, 48, 6608-6630.

3. Yang, J.; Sudik, A.; Wolverton, C.; Siegel, D.J. High capacity hydrogen storage materials: Attributes for automotive applications and techniques for materials discovery. Chem. Soc. Rev. 2010, 39, 656-675.

4. Reardon, H.; Hanlon, J.M.; Hughes, R.W.; Godula-Jopek, A.; Mandal, T.K.; Gregory, D.H. Emerging concepts in solid-state hydrogen storage the role of nanomaterials design. Energy Environ. Sci. 2012, 5, 5951-5979.

5. U.S. Department of Energy, Office of Energy Efficiency and Renewable Energy and the FreedomCAR and Fuel Partnership. Technical System Targets: Onboard Hydrogen Storage for Light-Duty Fuel Cell Vehicles. Available online: http://energy.gov/sites/prod/files/2014/03/f12/ targets_onboard_hydro_storage.pdf (accessed on 23 December 2014).

6. Urgnani, J.; Torres, F.J.; Palumbo, M.; Baricco, M. Hydrogen release from solid state $\mathrm{NaBH}_{4}$. Int. J. Hydrog. Energy 2008, 33, 3111-3115.

7. Martelli, P.; Caputo, R.; Remhof, A.; Mauron, P.; Borgschulte, A.; Züttel, A. Stability and decomposition of $\mathrm{NaBH}_{4}$. J. Phys. Chem. C 2010, 114, 7173-7177.

8. Milanese, C.; Garroni, S.; Girella, A.; Mulas, G.; Berbenni, V.; Bruni, G.; Suriach, S.; Baró, M.D.; Marini, A. Thermodynamic and kinetic investigations on pure and doped $\mathrm{NaBH}_{4}-\mathrm{MgH}_{2}$ system. J. Phys. Chem. C 2011, 115, 3151-3162.

9. Züttel, A.; Rentsch, S.; Fischer, P.; Wenger, P.; Sudan, P.; Mauron, P.; Emmenegger, C. Hydrogen storage properties of $\mathrm{LiBH}_{4}$. J. Alloys Compd. 2003, 356-357, 515-520.

10. Mao, J.F.; Guo, Z.P.; Liu, H.K.; Yu, X.B. Reversible hydrogen storage in titanium-catalyzed $\mathrm{LiAlH}_{4}-\mathrm{LiBH}_{4}$ system. J. Alloys Compd. 2009, 487, 434-438.

11. Mauron, P.; Buchter, F.; Friedrichs, O.; Remhof, A.; Bielmann, M.; Christoph, N.Z.; Züttel, A. Stability and reversibility of $\mathrm{LiBH}_{4}$. J. Phys. Chem. B 2008, 112, 906-910.

12. Yu, X.B.; Grant, D.M.; Walker, G.S. Dehydrogenation of $\mathrm{LiBH}_{4}$ destabilized with various oxides. J. Phys. Chem. C 2009, 113, 17945-17949.

13. Chłopek, K.; Frommen, C.; Léon, A.; Zabara, O.; Fichtner, M. Synthesis and properties of magnesium tetrahydroborate, $\mathrm{Mg}\left(\mathrm{BH}_{4}\right)_{2}$. J. Mater. Chem. 2007, 17, 3496-3503.

14. Li, H.W.; Kikuchi, K.; Nakamori, Y.; Miwa, K.; Towata, S.; Orimo, S. Effects of ball milling and additives on dehydriding behaviors of well-crystallized $\mathrm{Mg}\left(\mathrm{BH}_{4}\right)_{2}$. Scr. Mater. 2007, 57, 679-682.

15. Newhouse, R.J.; Stavila, V.; Hwang, S.-J.; Klebanoff, L.E.; Zhang, J.Z. Reversibility and improved hydrogen release of magnesium borohydride. J. Phys. Chem. C 2010, 114, 5224-5232. 
16. Mao, J.F.; Guo, Z.P.; Poh, C.K.; Ranjbar, A.; Guo, Y.H.; Yu, X.B.; Liu, H.K. Study on the dehydrogenation kinetics and thermodynamics of $\mathrm{Ca}\left(\mathrm{BH}_{4}\right)_{2}$. J. Alloys Compd. 2010, 500, 200-205.

17. Kim, Y.; Hwang, S.-J.; Lee, Y.S.; Suh, J.Y.; Han, H.N.; Cho, Y.W. Hydrogen back-pressure effects on the dehydrogenation reactions of $\mathrm{Ca}\left(\mathrm{BH}_{4}\right)_{2}$. J. Phys. Chem. C 2012, 116, 25715-25720.

18. Riktor, M.D.; Sørby, M.H.; Chopek, K.; Fichtner, M.; Haubac, B.C. The identification of a hitherto unknown intermediate phase $\mathrm{CaB}_{2} \mathrm{H}_{X}$ from decomposition of $\mathrm{Ca}\left(\mathrm{BH}_{4}\right)_{2}$. J. Mater. Chem. 2009, 19, 2754-2759.

19. Orimo, S.; Nakamori, Y.; Eliseo, J.; Züttel, A.; Jensen, C.M. Complex hydrides for hydrogen storage. Chem. Rev. 2007, 107, 4111-4132.

20. Li, H.W.; Yan, Y.G.; Orimo, S.; Züttel, A.; Jensen, C.M. Recent progress in metal borohydrides for hydrogen storage. Energies 2011, 4, 185-214.

21. Muir, S.S.; Yao, X.D. Progress in sodium borohydride as a hydrogen storage material: Development of hydrolysis catalysts and reaction systems. Int. J. Hydrog. Energy 2011, 36, 5983-5997.

22. U.S. Department of Energy Hydrogen Program. Go/No-Go Recommendation for Sodium Borohydride for On-Board Vehicular Hydrogen Storage; NREL/MP-150-42220; National Renewable Energy Laboratory (NREL): Golden, CO, USA, 2007.

23. Sigma-Aldrich. Available online: http://www.sigmaaldrich.com/united-states (accessed on 19 October 2014).

24. Santos, D.M.F.; Sequeira, C.A.C. Sodium borohydride as a fuel for the future. Renew. Sustain. Energy Rev. 2011, 15, 3980-4001.

25. Cakır, D.; Wijs, G.A.D.; Brocks, G. Native defects and the dehydrogenation of $\mathrm{NaBH}_{4}$. J. Phys. Chem. C 2011, 115, 24429-24434.

26. Grochala, W.; Edwards, P. Thermal decomposition of the non-interstitial hydrides for the storage and production of hydrogen. Chem. Rev. 2004, 104, 1283-1315.

27. Mao, J.; Guo, Z.; Yu, X.; Liu, H. Improved hydrogen storage properties of $\mathrm{NaBH}_{4}$ destabilized by $\mathrm{CaH}_{2}$ and $\mathrm{Ca}\left(\mathrm{BH}_{4}\right)_{2}$. J. Phys. Chem. C 2011, 115, 9283-9290.

28. Garroni, S.; Milanese, C.; Pottmaier, D.; Mulas, G.; Nolis, P.; Girella, A.; Caputo, R.; Olid, D.; Teixdor, F.; Baricco, M.; et al. Experimental evidence of $\mathrm{Na}_{2}\left[\mathrm{~B}_{12} \mathrm{H}_{12}\right]$ and $\mathrm{Na}$ formation in the desorption pathway of the $2 \mathrm{NaBH}_{4}+\mathrm{MgH}_{2}$ System. J. Phys. Chem. C 2011, 115, 16664-16671.

29. Ngene, P.; van den Berg, R.; Verkuijlen, M.H.W.; de Jong, K.P.; de Jongh, P.E. Reversibility of the hydrogen desorption from $\mathrm{NaBH}_{4}$ by confinement in nanoporous carbon. Energy Environ. Sci. 2011, 4, 4108-4115.

30. Friedrichs, O.; Remhof, A.; Hwang, S.-J.; Züttel, A. Role of $\mathrm{Li}_{2} \mathrm{~B}_{12} \mathrm{H}_{12}$ for the formation and decomposition of $\mathrm{LiBH}_{4}$. Chem. Mater. 2009, 22, 3265-3268.

31. Caputo, R.; Garroni, S.; Olid, D.; Teixidor, F.; Suriňach, S.; Dolors Baró, M. Can $\mathrm{Na}_{2}\left[\mathrm{~B}_{12} \mathrm{H}_{12}\right]$ be a decomposition product of $\mathrm{NaBH}_{4}$ ? Phys. Chem. Chem. Phys. 2010, 12, 15093-15100.

32. Mao, J.F.; Guo, Z.P.; Nevirkovets, I.P.; Liu, H.K.; Dou, S.X. Hydrogen de-/absorption improvement of $\mathrm{NaBH}_{4}$ catalyzed by titanium-based additives. J. Phys. Chem. C 2012, 116, 1596-1604.

33. Humphries, T.D.; Kalantzopoulos, G.N.; Llamas-Jansa, I.; Olsen, J.E.; Hauback, B.C. Reversible hydrogenation studies of $\mathrm{NaBH}_{4}$ milled with Ni-containing additives. J. Phys. Chem. C 2013, 117, 6060-6065. 
34. De Jongh, P.E.; Adelhelm, P. Nanosizing and nanoconfinement: New strategies towards meeting hydrogen storage goals. ChemSusChem 2010, 3, 1332-1348.

35. Varin, R.A.; Chiu, C. Structural stability of sodium borohydride $\left(\mathrm{NaBH}_{4}\right)$ during controlled mechanical milling. J. Alloys Compd. 2005, 397, 276-281.

36. Ampoumogli, A.; Steriotis, T.; Trikalitis, P.; Giasafaki, D.; Bardaji, E.G.; Fichtner, M.; Charalambopoulou, G. Nanostructured composites of mesoporous carbons and boranates as hydrogen storage materials. J. Alloys Compd. 2011, 509, S705-S708.

37. Peru, F.; Garroni, S.; Campesi, R.; Milanese, C.; Marini, A.; Pellicer, E.; Baró, M.D.; Mulas, G. Ammonia-free infiltration of $\mathrm{NaBH}_{4}$ into highly-ordered mesoporous silica and carbon matrices for hydrogen storage. J. Alloys Compd. 2013, 580, S309-S312.

38. Christian, M.L.; Aguey-Zinsou, K.F. Core-shell strategy leading to high reversible hydrogen storage capacity for $\mathrm{NaBH}_{4}$. ACS Nano 2012, 6, 7739-7751.

39. Christian, M.L.; Aguey-Zinsou, K.F. Synthesis of core-shell $\mathrm{NaBH}_{4} @ \mathrm{M}(\mathrm{M}=\mathrm{Co}, \mathrm{Cu}, \mathrm{Fe}, \mathrm{Ni}, \mathrm{Sn})$ nanoparticles leading to various morphologies and hydrogen storage properties. Chem. Commun. 2013, 49, 6794-6796.

40. Zhang, L.T.; Xiao, X.Z.; Fan, X.L.; Li, S.Q.; Ge, H.W.; Wang, Q.D.; Chen, L.X. Fast hydrogen release under moderate conditions from $\mathrm{NaBH}_{4}$ destabilized by fluorographite. $R S C A d v . \mathbf{2 0 1 4}, 4$, 2550-2556.

41. Mao, J.F.; Yu, X.B.; Guo, Z.P.; Liu, H.K.; Wu, Z.; Ni, J. Enhanced hydrogen storage performances of $\mathrm{NaBH}_{4}-\mathrm{MgH}_{2}$ system. J. Alloys Compd. 2009, 479, 619-623.

42. Garroni, S.; Pistidda, C.; Brunelli, M.; Vaughan, G.B.M.; Suriňach, S.; Baró, M.D. Hydrogen desorption mechanism of $2 \mathrm{NaBH}_{4}+\mathrm{MgH}_{2}$ composite prepared by high-energy ball milling. Scr. Mater. 2009, 60, 1129-1132.

43. Dornheim, M. Tailoring Reaction Enthalpies of Hydrides. In Handbook of Hydrogen Storage; Hirscher, M., Ed.; Wiley-VCH: New York, NY, USA, 2010; pp. 187-214.

44. Mao, J.F.; Yu, X.B.; Guo, Z.P.; Poh, C.K.; Liu, H.K.; Wu, Z.; Ni, J. Improvement of the $\mathrm{LiAlH}_{4}-\mathrm{NaBH}_{4}$ system for reversible hydrogen storage. J. Phys. Chem. C 2009, 113, 10813-10818.

45. Afonso, G.; Bonakdarpour, A.; Wilkinson, D.P. Hydrogen storage properties of the destabilized $4 \mathrm{NaBH}_{4} / 5 \mathrm{Mg}_{2} \mathrm{NiH}_{4}$ composite system. J. Phys. Chem. C 2013, 117, 21105-21111.

46. Li, G.Q.; Matsuo, M.; Deledda, S.; Hauback, B.C.; Orimo, S. Dehydriding property of $\mathrm{NaBH}_{4}$ combined with $\mathrm{Mg}_{2} \mathrm{FeH}$. Mater. Trans. 2014, 55, 1141-1143.

47. Garroni, S.; Milanese, C.; Girell, A.; Marini, A.; Mulas, G.; Meneňdez, E.; Pistidda, C.; Dornheim, M.; Suriňach, S.; Baró, M.D. Sorption properties of $\mathrm{NaBH}_{4} / \mathrm{MH}_{2}(\mathrm{M}=\mathrm{Mg}, \mathrm{Ti})$ powder systems. Int. J. Hydrog. Energy 2010, 35, 5434-5441.

48. Pottmaier, D.; Pistidda, C.; Groppo, E.; Bordiga, S.; Spoto, G.; Dornheim, M.; Baricco, M. Dehydrogenation reactions of $2 \mathrm{NaBH}_{4}+\mathrm{MgH}_{2}$ system. Int. J. Hydrog. Energy 2011, 36, 7891-7896.

49. Nwakwuo, C.C.; Pistidda, C.; Dornheim, M.; Hutchison, J.L.; Sykes, J.M. Microstructural analysis of hydrogen absorption in $2 \mathrm{NaH}+\mathrm{MgB}_{2}$. Scr. Mater. 2011, 64, 351-354.

50. Pistidda, C.; Garroni, S.; Minella, C.; Dolci, F.; Jensen, T.R.; Nolis, P.; Bösenberg, U.; Cerenius, Y.; Lohstroh, W.; Fichtner, M.; et al. Pressure effect on the $2 \mathrm{NaH}+\mathrm{MgB}_{2}$ hydrogen absorption reaction. J. Phys. Chem. C 2010, 114, 21816-21823. 
51. Pistidda, C.; Pottmaier, D.; Karimi, F.; Garroni, S.; Rzeszutek, A.; Tolkiehn, M.; Fichtner, M.; Lohstroh, W.; Baricco, M.; Klassen, T.; et al. Effect of $\mathrm{NaH} / \mathrm{MgB}_{2}$ ratio on the hydrogen absorption kinetics of the system $\mathrm{NaH}+\mathrm{MgB}_{2}$. Int. J. Hydrog. Energy 2014, 39, 5030-5036.

52. Garroni, S.; Minella, C.B.; Pottmaier, D.; Pistidda, C.; Milanese, C.; Marini, A.; Enzo, S.; Mulas, G.; Dornheim, M.; Baricco, M.; et al. Mechanochemical synthesis of $\mathrm{NaBH}_{4}$ starting from $\mathrm{NaH}-\mathrm{MgB}_{2}$ reactive hydride composite system. Int. J. Hydrog. Energy 2013, 38, 2363-2369.

53. Pistidda, C.; Barkhordarian, G.; Rzeszutek, A.; Garroni, S.; Bonatto Minella, C.; Baró, M.D.; Nolis, P.; Bormann, R.; Klassen, T.; Dornheim, M. Activation of the reactive hydride composite $2 \mathrm{NaBH}_{4}+\mathrm{MgH}_{2}$. Scr. Mater. 2011, 64, 1035-1038.

54. Mulas, G.; Campesi, R.; Garroni, S.; Napolitano, E.; Milanese, C.; Dolci, F.; Pellicer, E.; Baró, D.; Marini, A. Hydrogen storage in $2 \mathrm{NaBH}_{4}+\mathrm{MgH}_{2}$ mixtures: Destabilization by additives and nanoconfinement. J. Alloys Compd. 2012, 536, S236-S240.

55. Lemke, C.H. Sodium and sodium alloys. In Kirk-Othmer Encyclopedia of Chemical Technology; John Wiley \& Sons: New York, NY, USA, 1983; pp. 181-204.

56. Young, J.A. Sodium fluoride. J. Chem. Educ. 2002, 79, doi:10.1021/ed079p1197.

57. Yin, L.C.; Wang, P.; Kang, X.D.; Sun, C.H.; Cheng, H.M. Functional anion concept: Effect of fluorine anion on hydrogen storage of sodium alanate. Phys. Chem. Chem. Phys. 2007, 9, 1499-1502.

58. Rude, L.H.; Filsø, U.; D’Anna, V.; Spyratou, A.; Richter, B.; Hino, S.; Zavorotynska, O.; Baricco, M.; Sørby, M.H.; Hauback, B.C.; et al. Hydrogen-fluorine exchange in $\mathrm{NaBH}_{4}-\mathrm{NaBF}_{4}$. Phys. Chem. Chem. Phys. 2013, 15, 18185-18194.

59. Mao, J.F.; Guo, Z.P.; Liu, H.K.; Dou, S.X. Reversible storage of hydrogen in NaF-MB 2 (M = Mg, Al) composites. J. Mater. Chem. A 2013, 1, 2806-2811.

60. Zhang, Z.G.; Wang, H.; Zhu, M. Hydrogen release from sodium borohydrides at low temperature by the addition of zinc fluoride. Int. J. Hydrog. Energy 2011, 36, 8203-8208.

61. Kalantzopoulos, G.N.; Guzik, M.N.; Deledda, S.; Heyn, R.H.; Mullera, J.; Hauback, B.C. Destabilization effect of transition metal fluorides on sodium borohydride. Phys. Chem. Chem. Phys. 2014, 16, 20483-20491.

62. Chong, L.N.; Zou, J.X.; Zeng, X.Q.; Ding, W.J. Mechanisms of reversible hydrogen storage in $\mathrm{NaBH}_{4}$ through $\mathrm{NdF}_{3}$ addition. J. Mater. Chem. A 2013, 1, 3983-3991.

63. Zou, J.X.; Li, L.J.; Zeng, X.Q.; Ding, W.J. Reversible hydrogen storage in a $3 \mathrm{NaBH}_{4} / \mathrm{YF}_{3}$ composite. Int. J. Hydrog. Energy 2012, 37, 17118-17125.

64. Chong, L.N.; Zou, J.X.; Zeng, X.Q.; Ding, W.J. Effects of La fluoride and La hydride on the reversible hydrogen sorption behaviors of $\mathrm{NaBH}_{4}$ : A comparative study. J. Mater. Chem. A 2014, 2, 8557-8570.

65. Chong, L.N.; Zou, J.X.; Zeng, X.Q.; Ding, W.J. Study on reversible hydrogen sorption behaviors of a $3 \mathrm{NaBH}_{4} / \mathrm{HoF}_{3}$ composite. Int. J. Hydrog. Energy 2014, 39, 14275-14281.

66. Lu, J.; Fang, Z.Z.; Sohn, H.Y. A dehydrogenation mechanism of metal hydrides based on interactions between $\mathrm{H}^{\delta+}$ and $\mathrm{H}^{-}$. Inorg. Chem. 2006, 45, 8749-8754.

67. Chater, P.A.; Anderson, P.A.; Prendergast, J.W.; Walton, A.; Mann, V.S.J.; Book, D.; David, W.I.F.; Johnson, S.R.; Edwards, P.P. Synthesis and characterization of amide-borohydrides: New complex light hydrides for potential hydrogen storage. J. Alloys Compd. 2007, 446-447, 350-354. 
68. Somer, M.; Acar, S.; Koz, C.; Kokal, I.; Hohn, P.; Cardoso-Gil, R.; Aydemir, U.; Akselrud, L. $\alpha$ - and $\beta-\mathrm{Na}_{2}\left[\mathrm{BH}_{4}\right]\left[\mathrm{NH}_{2}\right]$ : Two modifications of a complex hydride in the system $\mathrm{NaNH}_{2}-\mathrm{NaBH}_{4}$; syntheses, crystal structures, thermal analyses, mass and vibrational spectra. J. Alloys Compd. 2010, 491, 98-105.

69. Wu, C.; Bai, Y.; Yang, J.H.; Wu, F.; Long, F. Characterizations of composite $\mathrm{NaNH}_{2}-\mathrm{NaBH}_{4}$ hydrogen storage materials synthesized via ball milling. Int. J. Hydrog. Energy 2012, 37, 889-893.

70. Drozd, V.; Saxena, S.; Garimella, S.V.; Durygin, A. Hydrogen release from a mixture of $\mathrm{NaBH}_{4}$ and $\mathrm{Mg}(\mathrm{OH})_{2}$. Int. J. Hydrog. Energy 2007, 32, 3370-3375.

71. Varin, R.A.; Parviz, R. Hydrogen generation from the ball milled composites of sodium and lithium borohydride $\left(\mathrm{NaBH}_{4} / \mathrm{LiBH}_{4}\right)$ and magnesium hydroxide $\left(\mathrm{Mg}(\mathrm{OH})_{2}\right)$ without and with the nanometric nickel (Ni) additive. Int. J. Hydrog. Energy 2012, 37, 1584-1293.

72. Nakamori, Y.; Miwa, K.; Ninoyiya, A.; Li, H.; Ohba, N.; Towata, S.; Züttel, A.; Orimo, S. Correlation between thermodynamical stabilities of metal borohydrides and cation electronegativities: First-principles calculations and experiments. Phys. Rev. B 2006, 74, doi:10.1103/PhysRevB. 74.045126.

73. Nakamori, Y.; Li, H.W.; Kikuchi, K.; Aoki, M.; Miwa, K.; Towata, S.; Orimo, S. Thermodynamical stabilities of metal-borohydrides. J. Alloys Compd. 2007, 446-447, 296-300.

74. Seballos, L.; Zhang, J.Z.; Rönnebro, E.; Herbergd, J.L.; Majzoub, E.H. Metastability and crystal structure of the bialkali complex metal borohydride $\mathrm{NaK}\left(\mathrm{BH}_{4}\right)_{2}$. J. Alloys Compd. 2009, 476, 446-450.

75. Llamas-Jansa, I.; Aliouane, N.; Deledda, S.; Fonneløp, J.E.; Frommen, C.; Humphries, T.; Lieutenant, K.; Sartori, S.; Sørby, M.H.; Hauback, B.C. Chloride substitution induced by mechano-chemical reactions between $\mathrm{NaBH}_{4}$ and transition metal chlorides. J. Alloys Compd. 2012, 530, 186-192.

76. Černý, R.; Severa, G.; Ravnsbæk, D.B.; Filinchuk, Y.; D’Anna, V.; Hagemann, H.; Haase, D.; Jensen, C.M.; Jensen, T.R. NaSc(BH4)4: A novel scandium-based borohydride. J. Phys. Chem. C 2010, 114, 1357-1364.

77. Ravnsbæk, D.; Filinchuk, Y.; Cerenius, Y.; Jakobsen, H.J.; Besenbacher, F.; Skibsted, J.; Jensen, T.R. A series of mixed-metal borohydrides. Angew. Chem. Int. Ed. 2009, 48, 6659-6663.

78. Xia, G.L.; Li, L.; Guo, Z.P.; Gu, Q.F.; Guo, Y.H.; Yu, X.B.; Liu, H.K.; Liu, Z.W. Stabilization of $\mathrm{NaZn}\left(\mathrm{BH}_{4}\right)_{3}$ via nanoconfinement in SBA-15 towards enhanced hydrogen release. J. Mater. Chem. A 2013, 1, 250-257.

79. Ravnsbæk, D.B.; Ley, M.B.; Lee, Y.S.; Hagemann, H.; D’Anna, V.; Cho, Y.W.; Filinchuk, Y.; Jensen, T.R. A mixed-cation mixed-anion borohydride $\mathrm{NaY}\left(\mathrm{BH}_{4}\right)_{2} \mathrm{Cl}_{2}$. Int. J. Hydrog. Energy 2012, 37, 8428-8438.

80. Hummelshøj, J.S.; Landis, D.D.; Voss, J.; Jiang, T.; Tekin, A.; Bork, N.; Dułak, M.; Mortensen, J.J.; Adamska, L.; Andersin, J.; et al. Density functional theory based screening of ternary alkali-transition metal borohydrides: A computational material design project. J. Chem. Phys. 2009, 131, doi:10.1063/1.3148892.

(C) 2015 by the authors; licensee MDPI, Basel, Switzerland. This article is an open access article distributed under the terms and conditions of the Creative Commons Attribution license (http://creativecommons.org/licenses/by/4.0/). 